\title{
Transatlantic Integration: The TTIP under Scrutiny
}

\author{
Daniel Nagel \\ Bucharest University of Economic Studies, Bucharest, Romania
}

\begin{abstract}
In view of the already relatively low most-favored-nation (MFN) rates on average, today's most impeding barriers to transatlantic trade are not custom tariffs but so-called behind-the-border measures. TTIP was originally destined to become a verily comprehensive trade and investment agreement in acknowledgment of this circumstance. But its distinctively ambitious agenda exposed both camps' opposing positions on several fronts at the same time. Considering that the negotiations had already hit several road blocks under the espousing Obama administration, the protectionist convictions and "America First" policy of the incumbent US President promised to complicate many of these contentious issues. Cherished as a popular tool in the business environment, the SWOT analysis also stood the test in the innovative context of identifying internal strengths and weaknesses of TTIP as well as external opportunities and threats to its conclusion further down the line. Juxtaposing its intrinsic strengths and weaknesses of TTIP unveils a mixed picture, alike so often in real life where no absolute truth exists. Nevertheless, the research demonstrates that there are compelling economic incentives for revitalizing the bilateral talks with respect to the likely transformations it would bring about in terms of market organization and functioning, production and distribution efficiency, national income, consumer satisfaction and, not least, regulation harmonization. Examining the matter from a different angle by asking "What are the probable implications of the scenario where the negotiations on a transatlantic trade and investment agreement will not be reinstated in the near future?" provided further illuminating insights. This approach revealed that neither the EU nor the US can actually afford to perpetuate the current status quo. Without TTIP, the relative size of the transatlantic pole is bound to dwindle in the global economy. Let alone the long-term geostrategic damage caused by its absence, as the EU and the US would miss out on the last chance to impose their joint vision of 21 st century commerce on the rest of the world and preempt China from doing so instead. A glance at the corresponding external opportunities and threats suggests that the pendula could swing in either direction in terms of the TTIP's destiny. The author believes that Brussels will be hesitant to re-embark on delicate trade negotiations until the next US presidential election, in the hope that a more amicable and more reliable counterpart would enter the White House. The Commission will be too distracted anyway by the coinciding Brexit from taking the initiative any time soon. The UK's exit represents a double-edged sword in this context, as the dueling race for a Free Trade Agreement (FTA) with the US will immediately start once this all-consuming affair is settled and tied up capacities are recuperated. But for also reaching the finishing line - synonymous for the successful ratification of TTIP — it is imperative to learn from the mistakes of the past. Aloof officials have to put themselves in the shoes of ordinary citizens if they want to formulate convincing narratives and draw the right lessons from previous mistakes.
\end{abstract}

Keywords: TTIP, transatlantic trade, transatlantic integration, SWOT analysis, Free Trade Agreement

Daniel Nagel, Ph.D. student, Doctoral School of Economics and International Business, Bucharest University of Economic Studies, Bucharest, Romania. 


\section{The Road Toward a Fully Integrated Transatlantic Market: Winding and Potholed}

The European integration process reportedly played a decisive role in shaping transatlantic relations by ushering in an era of greater cohesion (Müftüler \& Cihangir, 2012). Firstly, the attendant institutional reforms elevated the EU on a level playing field with the US (Smith, 2010). Secondly, national governments had to relinquish their sovereignty in the realm of commercial policy when by the decree of the 2007 Lisbon Treaty the steering of any affairs related to international trade fell in the remit of the European Commission.

The first try of integrating the transatlantic economy intriguingly dates back a long time ago, namely to the Transatlantic Declaration in 1990. It was followed by several other initiatives to institutionalize cooperation on regulation issues, exemplified by the New Transatlantic Agenda in 1995 or the Transatlantic Economic Partnership in 1998. However, the big breakthrough in regulatory alignment - let alone the vision of a Trans-Atlantic Free Trade Agreement (TAFTA) which had been sporadically on the table-had consistently failed to materialize (Pollack, 2003; Posner, 2009; Steffenson, 2005). Against this background, US President Bush, European Commission President Barroso, and German Chancellor Merkel—who was also President of the European Council at that time-founded the Transatlantic Economic Council (TEC) in 2007 in order to guide and expedite the progress on EU/US regulatory convergence (TABC, 2017). The Transatlantic Business Dialogue (TABD), the Transatlantic Consumer Dialogue (TACD), and the Transatlantic Legislator's Dialogue (TLD) were additionally allocated as designated advisory groups to the TEC (Ahearn, 2009; EC, 2017c). The High-Level Working Group on Jobs and Growth (HLWG) was in the following established at the behest of the 28 November 2011 EU-US Summit meeting (EC, 2011). Led by the EU Trade Commissioner and the US Trade Representative (USTR), it was tasked with identifying policies and measures to stimulate bilateral trade and investment to support mutually beneficial job creation, economic growth, as well as international competitiveness. The HLWG's final report was published on 13 February 2013, recommending "a comprehensive agreement that addresses a broad range of bilateral trade and investment issues, including regulatory issues, and contributes to the development of global rules, would provide the most significant mutual benefit of the various options (...) considered" (HLWG, 2013). Moreover, it shall

be designed to evolve over time-i.e., substantially eliminate existing barriers to trade and investment, while establishing mechanisms that enable a further deepening of economic integration, particularly with respect to the promotion of more compatible approaches to current and future regulation and standard-setting. (HLWG, 2013)

US President America Barack Obama, European Commission President José Manuel Barroso, and European Council President Herman Van Rompuy consensually endorsed the HLWG's proposal when they unhesitatingly announced that each side will initiate the necessary internal procedures to launch negotiations on a Transatlantic Trade and Investment Partnership (TTIP) agreement (EC, 2013a). The author is convinced that the EU's 2006 shift in trade policy—emulating the US' preceding reorientation towards preferential trade agreements - was a fundamental premise for this line of events.

Since the US Congress has a say in all pivotal trade matters, the executive branch depends on the latter's issuance of the so-called Trade Promotion Authority for obtaining unrestricted negotiation power. In June 2013, the Senate and the House of Representatives granted such power of attorney to the US administration after fierce controversy. On the other side of the Atlantic, the $28 \mathrm{EU}$ member states had to confer a corresponding negotiating mandate on the EU Commission in whose remit trade policy falls. The EU member states only disclosed the content of the mandate after vehement public pressure and after the document had been leaked 
anyway. Concisely, its main objective is to reinforce economic relations between the US and the EU for the sake of boosting growth and jobs.

The TTIP negotiations per se were basically dissected in more than 20 working groups on various subjects. Up to 190 representatives, mostly civil servants from the EU Commission and the US Department of Commerce attended these working sessions. While their exact circle of participants was not made public, the negotiators also interacted upon demand with stakeholders from industry, agriculture, environmental protection, etc., as a medium to voice concerns. While EU Commissioner for Trade, Cecilia Malmström was by definition politically accountable for the TTIP negotiations, Ignacio Garcia Bercero from the Directorate-General for Trade acted as the chief negotiator of the European Commission. Former Trade Representative Michael Froman (Office of the USTR) and chief negotiator Dan Mullaney represented their respective counterparts on the US side. The talks encompassed several summits with different thematic focuses (e.g., public procurement, investment protection, etc.) and were convened alternately in Washington and Brussels.

It was originally scheduled that the bulk framework of the agreement had to be fixed until the end of 2015 . The goal was to conclude the deal by all means under an espousing President Obama before a new US administration with possibly different motives, attitudes, and demands would take over in January 2017. However, partly incompatible positions on various issues led, with the benefit of hindsight, to fatal delays beyond this due date. New York hosted the latest of these 15 TTIP rounds overall in October 2016 whereas the actual drafting work was sustained at technical level until January 2017 (BMWI, 2017b). A concurrent state of play report admitted that in spite of significant strides towards finding common ground, mutual assent was still pending for any of the treaty's almost 30 chapters (Malmstroem \& Froman, 2017). The talks were then abruptly suspended in January 2017 when with President Trump's inauguration the new US administration took office and are yet to be resumed.

The movement of transatlantic integration was revitalized on 15 February 2017 when the European Parliament voted in favor of Comprehensive Economic and Trade Agreement (CETA), though. The Comprehensive Economic and Trade Agreement pledges to curtail over $98 \%$ of duties and other impeding barriers to trade between Canada and the EU (EC, 2017b). CETA will not only lead the way in improving market access for industrial goods but also agricultural produce, services, investment, and government procurement. Except safeguarding environmental protection and labor rights, a core element of the agreement lies in the domain of investment protection. CETA distinguishes itself from former Free Trade Agreements (FTAs) by establishing an independent and transparent Investment Court System (ICS) in contrast to the contentious ISDS (investor-state dispute settlement) mechanism (BMWI, 2017a). Besides, a revision of the preexisting EU-Mexico Free Trade Agreement has been initiated in 2016 to emulate the extensive abolition of trade barriers attained by contemporary FTAs (EC, 2017a). Since the US consequently remains the only NAFTA (North American Free Trade Agreement) member the EU has not yet struck a trade accord with, the author opines that TTIP denotes the next logical step in the process of transatlantic integration. The recent achievements on CETA and JEFTA (Japan-EU Free Trade Agreement) clearly demonstrate that legislators in Brussels have retained their liberal mindset throughout. Despite all the protectionist rhetoric of the incumbent president, leading representatives of the US government have reportedly signaled their interest in reviving the bilateral talks on a FTA with the EU in the medium term (Spiegel, 2017). Though, this unlikely to materialize until President Trump will have satisfied his electoral base by delivering on one of his campaign promises, i.e., to reform NAFTA to the US' s advantage. 


\section{Objectives and Research Methodology}

Within this article, the author shall investigate whether there are compelling motives for revitalizing the bilateral negotiations on an EU-US trade and investment agreement, be it under the technical term TTIP or rebranded. To achieve this research objective, the author is going to apply the following research methodology. Firstly, the author shall dwell on the three pillars of the former negotiations and their main subjects in order to lay the ground works for any profound assessment. Secondly, the author shall scrutinize the various points of contention which impede the conclusion of a transatlantic trade and investment agreement, utilizing comparative analysis to pinpoint the EU's and US's opposing positions on diverse issues. Thirdly, the author is going to conduct a SWOT analysis, whose schema is sketched in Figure 1. It represents a popular tool in the business environment when it comes to identifying internal and external factors that are favorable and unfavorable to an enterprise's ventures or projects. Strengths and weaknesses feature inherent characteristics of the business or project, whereas opportunities and threats focus on elements in the environment that could either be exploited to its advantage or could possibly cause some trouble.

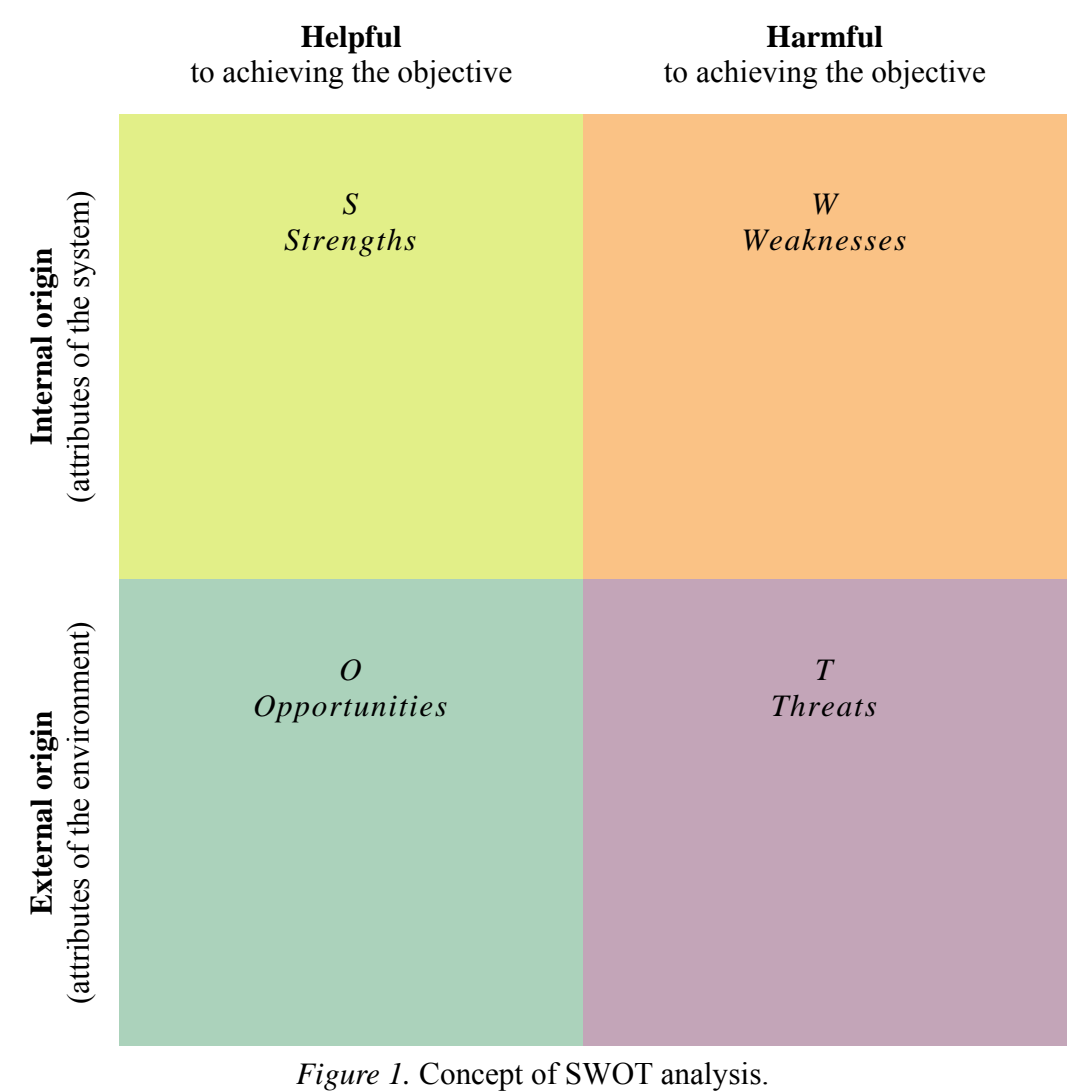

The author shall then adapt this powerful evaluation technique to identify the strengths, weaknesses, opportunities, and threats related to a potential conclusion of an EU-US trade and investment agreement further down the line. Denoting an innovative approach towards answering these contemporary research questions, the adapted model will pertinently outline:

(a) Internal strengths: Intrinsic benefits and advantages of a potential prospective transatlantic trade and investment partnership. 
(b) Internal weaknesses: Intrinsic flaws and imperfections of a potential prospective transatlantic trade and investment partnership.

(c) External opportunities: Conducive circumstances and proponents in favor of revitalizing bilateral negotiations towards a successful conclusion of transatlantic trade and investment partnership after all.

(d) External threats: Adverse circumstances and opponents which obstruct a resumption of the bilateral talks, shattering the vision of an EU-US trade and investment partnership.

The SWOT exercise, inter alia, draws on prospective analysis in order to forecast both the implications of external factors on the TTIP's destiny and its likely transformations in terms of market organization and functioning, business consolidation, production and distribution efficiency, consumer satisfaction, and regulation harmonization. The author shall also examine the TTIP from a different angle in order to enrich and buttress the line of argument. What are the consequences and ramifications of a perfectly conceivable scenario where the negotiations on a transatlantic trade and investment agreement will not be reinstated at some point in the future? Deploying this methodology, namely the antithesis, the author is able to investigate by implication whether and why a resumption of the bilateral talks culminating in the treaty's conclusion is desirable after all.

\section{TTIP in a Nutshell: Structure \& Substance}

TTIP was destined to attain ambitious outcomes in three broad domains (Council of the European Union, 2013; Kahn, Pallot, Taylor, \& Kanavos, 2015; WTO, 2016): (1) improved market access for industrial goods, agricultural products, services, and government procurement through abolishing custom duties and tackling non-tariff barriers (NTBs); (2) regulatory issues including not only horizontal chapters on regulatory coherence and TBTs (technical barriers to trade) but also specific sectoral alignment; (3) broader trade related rules as well as joint development of golden standards on WTO+ and WTO-X type disciplines. A concise overview of the partnership's fundamental structure is displayed in Figure 2.

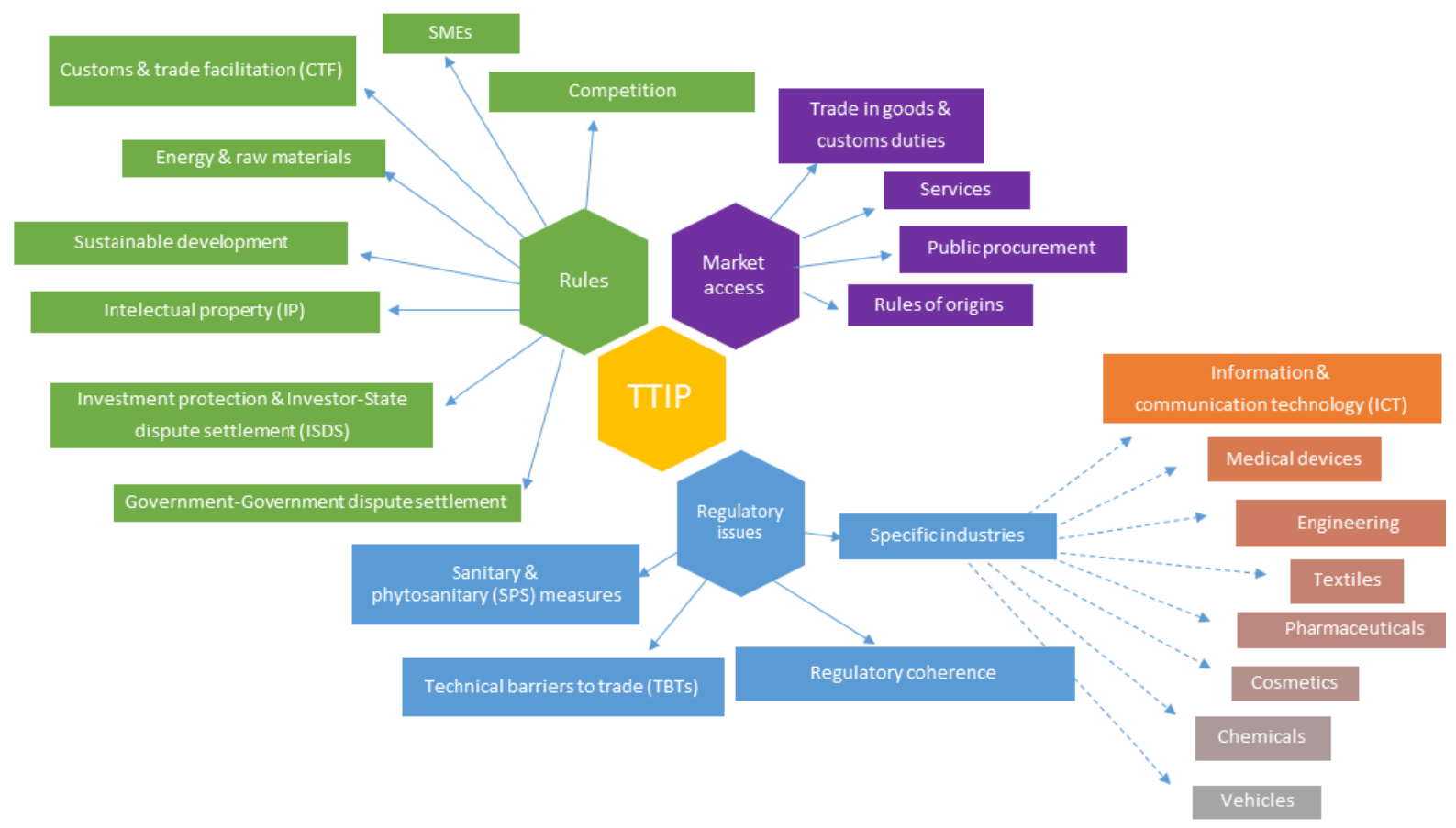

Figure 2. Structure of TTIP; based on Hamilton and Pelkmans (2015). 
A clear dissection into these three areas is rather complex as the multifaceted themes are often intertwined. Regulatory cooperation for instance kills two birds with one stone by reducing NTBs and improving market access for goods as well as services. Having said that, Below, the author is going to briefly outline the key subjects integral to TTIP (Akhtar \& Jones, 2014; Council of the European Union, 2013; EC, 2013a; HLWG, 2013):

\section{Tariffs on Goods and Agricultural Products}

The declared goal of the agreement was to sweepingly eliminate custom duties on bilateral trade in industrial and agricultural products upon entry into force and a phasing out of all remaining except of the most sensitive tariffs in a short time frame. At present, each other's imports are governed by the most-favored-nation (MFN) or normal trade relations (NTR) rate. The latest WTO (2018b) data show that simple applied tariff rate are relatively modest on average with $3.5 \%$ for the US and $5.2 \%$ ad valorem for the EU. Given the magnitude of mutual trade between both parties, even those fairly low average tariffs still implicate enormous overall costs to businesses. Considerable tariff peaks moreover affect certain import-sensitive product categories, e.g., dairy and fish products, sugar and confectionery, beverages and tobacco, as well as textiles and apparel. Lifting of tariffs was thus classified as the "low-hanging fruit" in the negotiations.

\section{Services}

The overarching term services encompasses accounting, banking, insurance, legal, transportation, e-commerce, retail, express, delivery, education tourism, telecommunications, and countless other fields of business activity. TTIP negotiators did not only aim at the highest level of service liberalization captured within existing FTAs but were instructed to go even further. They were directed to address longstanding barriers between the two GATS (General Agreement on Trade in Services) signatories, step up regulatory cooperation where appropriate and draft binding commitments in order to ensure transparency, impartiality and due process regarding licensing service providers as well as mutual recognition of professional qualification.

\section{Digital Trade and E-commerce}

The Internet ascended in this day and age to an indispensable platform for digital trade and e-commerce. Firms heavily depend on it for internal organization (i.e., communicating with employees, receiving orders, etc.), integration of peripheral business processes (i.e., supply chain management, invoicing, etc.), and executing transactions on a global scale. The wide range of possibilities for individuals and businesses to connect and exchange information via the Internet is, however, occasionally restricted by national governments that seek to regulate the cross-border flow of data. This motivation is mostly premised on justifiable reasons, such as thwarting illicit activities or government concerns about dispute settlement or contract enforcement in light of the Internet's rapid rise as a business platform (Meltzer, 2015). Interfering with the free flow of data is ill-founded in cases where measures seem discriminatory and constitute a type of localization barrier to trade. The final HLWG report thus proposed to implement bilateral disciplines in localization barriers to trade with a view to an ensuing global role out. Data privacy and protection posed yet another delicate issue during the TTIP negotiations, aggravated by the unauthorized disclosure of classified information on NSA (National Security Agency) surveillance activity since June 2013.

\section{Government Procurement}

Even though both acceded to the plurilateral WTO Agreement on Government Procurement, the GPA 
merely guarantees its contracting parties limited market access to some government entities and contracts worth more than a specified threshold value. Against this backdrop, the HLWG consequently urged TTIP negotiators to deliver nondiscriminatory mutual access to government procurement opportunities at all levels of government, not solely the federal one.

\section{Agriculture}

"Although not specifically mentioned in the HLWG final report or the official congressional notification, agriculture, in particular, is a sector in which the incompatibility of regulations (...) has led to long, difficult, and high-profile transatlantic trade disputes" (Akhtar \& Jones, 2014). Agricultural issues, such as sanitary and phytosanitary (SPS) measures or genetically modified organisms (GMOs) were thus fiercely contested in the context of market access and regulations.

\section{Industrial Regulations and Standards}

Today's most impeding barriers to transatlantic trade are not custom tariffs but so-called "behind-the-border" measures, wherefore regulatory issues and non-tariff barriers were deemed to be the core element of the TTIP talks. The WTO Agreement on TBTs bestows the right upon its signatories to stipulate their own standards but demands in return that corresponding measures are transparent, serve legitimate objectives, and do not hamper trade unnecessarily. Akin to SPS measures, the two members were supposed to entrench TBT+ commitments within the agreement, whose clear aim is to "yield greater openness, transparency, and convergence in regulatory approaches and requirements and related standards-development processes, as well as (...) to reduce redundant and burdensome testing and certification requirements" (HLWG, 2013). In that spirit, both parties aspired to address technical barriers to trade (TBTs) by means of harmonizing or mutually accepting each other's technical regulations, standards, and conformity assessment procedures. The same applies along the vertical dimension, i.e., accomplishing regulatory compatibility in specific sectors as illustrated above. Through mutual recognition arrangements (MRAs) "regulators agree to accept products or services from another jurisdiction under specified conditions, so that actors complying with the regulations in one jurisdiction will be considered to be in compliance with the rules in another jurisdiction" (Akhtar \& Jones, 2014). MRAs basically rest on "tested once" criteria in order to avoid the efforts and expenses of redundant testing when accessing the partner's market. Harmonization of standards or rules across both jurisdictions denotes in this context an even stronger form of cooperation. Anyway, "since not all regulatory divergences can be eliminated in one go, both sides envisage a living agreement that allows for progressively greater regulatory convergence over time against defined targets and deadlines" (EC, 2013a). In addition, they were supposed to install a framework for improved dialogue and cooperation for developing new regulation and standards. The American Chamber of Commerce to the EU is convinced that this could be achieved through a joint consultation process on the basis of impact and risk assessments involving stakeholder consultation (Gibbons, 2012).

\section{Investment}

With stocks of $€ 2391.1$ billion, the US represents an elemental source for Europe's inward FDI, whereas with EU outward stocks of $€ 2744.0$ billion, this statement applies in reverse as well (EC, 2017c). Premised on the most open business environments in the world, mutual investment is in fact a driving force of the transatlantic relationship as a third of bilateral trade arises from intra-company transfers. Thus, it is not surprising that both parties are proponents for easing restrictions on FDI and protecting investor rights. Despite 
of the European member states' roughly 1,200 bilateral investment treaties (BITs) and the US's over 40 federal BITs - whereby seven of these involve EU member states - in force, no overarching one exist so far between the two. This leaves transatlantic investment flows governed by an "incomplete" network of BITs in the concurring absence of a comprehensive multilateral treaty on investment rules (Akhtar \& Jones, 2014). The official goal of diplomats was thus to anchor the highest levels of liberalization and investment protection within TTIP that both sides have obtained to date in previous trade deals (EC, 2013a). Crucially, this holds out the prospect to shape global investment rules for generations to come.

\section{Intellectual Property Rights}

In spite of their subscription to the WTO Agreement on Trade-Related Aspects of Intellectual Property Rights (TRIPS), the two amicable blocs have consistently targeted TRIPS+ provisions in their previous PTAs. Protection and enforcement of Intellectual Property Rights (IPR) are essential for their innovation driven economies whose sustaining competiveness is susceptible to counterfeiting or piracy. Though, it would pose a tremendous struggle to entirely reconcile each side's typical bilateral IPR obligations. The HLWG (2013) therefore wittingly recommended that they should "explore opportunities to address a limited number of significant IPR issues of interest to either side, without prejudice to the outcome". Typical IPR domains cover geographical indications, patents, copyright protection, and trade secrets, whose misappropriation has been sadly on the rise with the ramping up of cybercrime. In this context, the Uniform Trade Secrets Act (§1(4)) defines trade secrets as any type of valuable "information, including a formula, pattern, compilation, program device, method, technique, or process, that: (i) derives independent economic value (...) from not being generally known to, and not being readily ascertainable (...) and (ii) is the subject of efforts (...) to maintain its secrecy".

\section{Trade Facilitation}

Trade facilitation refers to the simplification, modernization, and streamlining of import and export procedures for the purpose of enhanced efficiency in order to ultimately slash the costs of moving goods across borders (Jones \& Rosenblum, 2013). The WTO (2012) defined trade procedures as "activities, practices and formalities involved in collecting, presenting, communicating and processing data and other information required for the movement of goods in international trade". Trade facilitation hence necessitates cutting unnecessary red tape, providing easier access to relevant information, and reducing bureaucratic delays trough expeditious communication as well as cooperation between border agencies (Moïsé, Orliac, \& Minor, 2011). Because it does not only reduce costs but also improves the predictability and operability of global supply chains, Washington and Brussels advocate for trade facilitation on multiple fronts. Their stance did not only fed into in their bilateral PTAs but also multilaterally initiatives, exemplified by the landmark TFA (Trade Facilitation Agreement) at the 2013 Bali Ministerial Conferenceand attempts within the World Customs Organization (WCO) to expedite the clearance of merchandise entries via the usage of a universal electronic system. The author believes that TTIP could have functioned as a launching pad of global relevance for the unification of all these best practices.

\section{Labor and Environment}

Since both have been championing labor rights and environmental protection in their former PTAs, the final HLWG report recommends that Brussels and Washington "explore opportunities to address these important issues, taking into account work done in the Sustainable Development Chapter of EU trade 
agreements and the Environment and Labor Chapters of U.S. trade agreements" (HLWG, 2013).

\section{Localization Barriers to Trade}

As explained above, localization barriers to trade implicate a sort of NTB to market access. They are "designed to protect, favor, or stimulate domestic industries, service providers, or intellectual property at the expense of imported goods, services, or foreign-owned or foreign-developed intellectual property" (Akhtar \& Jones, 2014). Their broad spectrum of manifestations is verily striking. They, inter alia, compel financial service providers to process data on-shore, impose on online service providers to put up physical infrastructure, condition market access on the transfer of technology and intellectual property, require the usage of local content as a condition for manufacturing or for government procurement, and so forth. While their trade distorting effect may provoke a viscous circle of emulation, they are predominantly encountered in emerging economies, spearheaded by China and India (USTR, 2013). The HLWG (2013) prudently advised Brussels and Washington to "reach bilateral agreement on globally relevant rules, principles, or modes of cooperation related to localization barriers to trade".

\section{State-Owned Enterprises}

State-Owned Enterprises (SOEs) are enterprises where government exerts considerable control through full or majority ownership. In sharp contrast to their non-domestic equivalents in private hands, they are often granted specific privileges by governments, i.e., trade protection or preferential access to financing and government procurement. These practices have naturally incited strong resentment in both the EU and the US. Reproaching these governments for anti-competitive behavior and discriminatory treatment, they contemplated extending the sphere of potential TTIP provisions to third countries. These kinds of reining provisions typically deal with national treatment, non-discrimination, and transparency while still honoring nations' inherent right to run SOEs.

\section{SMEs}

Small- and medium- sized enterprises form the backbone of the American and European economy. As opposed to multinational enterprises (MNEs), many SMEs struggle to leverage their export potential because they cannot afford to assign scarce staff to gathering information about foreign markets and regularly regimes, not to speak of the incurring legal and bureaucratic costs associated with TBTs. In this sense, TTIP was supposed to facilitate access to trade financing and top off previous efforts to improve the availability of information on divergent regulations while significantly reducing transatlantic NTBs altogether.

\section{Dispute Settlement}

It transpired in the course of the negotiations that the discussions around dispute settlement are emotionally charged ones. While mechanisms for resolving related government-to-government disputes are normally incorporated into FTAs, a platform for investor-state disputes settlement was also contemplated in spite of considerable reservations by the European public.

\section{Points of Contention: The EU's and US' Opposing Positions During the Negotiations}

As elucidated above, the TTIP is distinctive for its comprehensive and ambitious agenda. It is fair to say, though, that the manifolds points of contention-revealing mercilessly both parties' deeply entrenched opposing positions on several issues - caused delegates a headache. To come to the point first, the author strongly believes that the concurrence of these multiple contentious issues eventually provoked - apart from 
political factors - the suspension of TTIP talks.

\section{Agriculture and Foodstuffs}

The subject domain "agriculture and food" certainly represents one of the most fiercely contested topics because of the current above-average tariff lines, the divergent production models, subsidies, and regulations on either side of the Atlantic. The author is going to demonstrate that the agricultural and food sector is symptomatic for the opposing transatlantic positions spanning all three pillars of the TTIP, namely market access, rules, and regulations altogether. While the US' and the EU's import duties on goods in total are relatively low with simple average MFN tariff rates of $3.5 \%$ and $5.2 \%$, the ones for specifically agricultural produce are substantially higher with rates of 5.2\% and $11.1 \%$, respectively (WTO, 2018a; 2018c). Even though agricultural and food products make up merely $5 \%$ of bilateral trade, multiple items are subject to flagrantly protectionist import duties. Applied European MFN duties on dairy facing up to $96 \%$ and American ones on tobacco hovering around $350 \%$ are just a couple of many prominent examples. In comparison with industrial goods, where the highest EU tariffs are imposed on trucks (22\%), followed by some footwear (17\%), audio-visual products (14\%), and clothing (12\%), the old continent's tariff peaks are indeed concentrated on the agricultural sector (EC, 2013a). While the US' tariff hikes in agriculture are generally speaking slightly lower in direct comparison, the ones concerning merchandise are more exhaustive, exemplified by textiles (40\%) or leather and footwear (56\%). Eliminating import duties on most products was in fact deemed to be the low hanging fruit in TTIP negotiations. Achieving mutual consent in terms of food products, processes, and standards proved challenging nonetheless. The US' agricultural sector is distinctive for its huge farms endowed with arable land of 447 hectares on average (MacDonald, 2013), whereas a typical rural holding in Germany features only 56 hectares (Federal Ministry of Food and Agriculture, 2011). It connotes that the achievable economies of scale are poles apart. The same applies to the accordingly divergent production methods, i.e., the prevalent cultivation of GMOs (genetically modified organisms) or usage of hormones and chemicals in the US. In fact, many Europeans citizens are anxious that a TTIP could undermine their highly cherished provisions on consumer protection.

American farmers are permitted to use several pesticides, chemicals, or hormones that are banned in the EU (BEUC, 2014). Examples are the widespread application of antibiotics in poultry farming, lactic acid in treating pork as a mode of decontamination or chlorine in the preservation of chicken. Notably, civil society groups portrayed chlorinated chicken as a symbol of the detriments a TTIP would bring about for European consumers. The disparate sanitary and phytosanitary rules across the Atlantic basically stem from radically different regulatory philosophies concerning approval or labelling requirements for certain processes or products. Without any doubt, the dissimilar approaches to risk management have featured prominently in the debates over TTIP (Buchter, Pinzler, \& Uchatius, 2014). The risk-adverse EU predominantly applies the precautionary principle where products - laid down in Regulation (EC) No. 178/2002 specifically for food and feed safety - are solely permitted onto the market after having been evinced harmless to consumers. Market authorization is denied when "scientific information is insufficient, inconclusive, or uncertain and where there are indications that the possible effects on the environment, or human, animal or plant health may be potentially dangerous" (Council, 2000). The Americans, on the other hand, insist on precedence for scientifically sound risk assessments. More precisely, the Code of Federal Regulation (21 CFR 170.3(i)) recognizes that it is simply impossible to ascertain that something is absolutely safe to every individual in every circumstance, wherefore foodstuff is allowed to penetrate the US market based on "reasonable certainty in the minds of competent scientists that the substance is not harmful under 
the intended conditions of use" until proven otherwise.

This goes hand in hand with the American principle of "substantial equivalence" which stipulates that a newly developed aliment is just as safe as an existing one given the same composition. Since the FDA (Food and Drug Administration) recognizes GMOs (genetically modified organisms) in substance equivalent to their conventional non-GMO counterparts (FDA, 1992), the American authorities do neither subject them to any safety tests nor an official pre-market approval process but rely on manufacturers alone when it comes to evaluating associated risks and accrediting GRAS (Generally Recognized as Safe) status (Bartl \& Fahey, 2014). The US's class action system offers American consumers in return an effective recourse to assert compensation claims against producers in the event of an adverse incident. This is in stark contrast with the EU's concept, where the EFSA (European Food Safety Authority) takes charge of this matter while the final green light for both cultivation and direct sale additionally depends on the benevolence of so-called risk managers, namely the European Commission, the European Parliament, and member states (BEUC, 2014).

On top of American businesses' resentment towards these allegedly lengthy and tedious European approval procedures, labelling of GMO containing foods is, as opposed to the US, compulsory in the EU according to Regulation (EC) 1830/2003. It moreover dictates that the traceability of GMOs and any derivates must be guaranteed throughout the entire production chain (Diels \& Thorun, 2015; Shao, Punt, \& Wesseler, 2015). Overall, the American biotech and food industry perceives those European provisions altogether as impeding NTBs, allegedly making European consumers believe that their GMO containing produced were not safe (Blenkinsop, 2014). The clash of American business interests with concerns of EU regulators over consumer protection has already culminated in a WTO trade dispute in the beginning of this millennium which is still ongoing. The US insinuates in this context that the EU's precautionary principle is merely a smokescreen to disguise protectionist measures on grounds of risk prevention. What the US regards as a barrier to trade is, however, figuratively treated like a holy cow on European shores, fueled by protests from farmers, environmentalists, and most importantly European consumers. Against this backdrop, it is perfectly plausible that in the beginning of this decade merely $0.12 \%$ of arable land was dedicated to cultivation of GMOs in the EU (Schimpf, 2013), in comparison with startling 50\% in the US (Fernandez-Cornejo, Wechsler, Livingston, \& Mitchell, 2014).

Both regulatory regimes also differ in view of the food chain per se. The EU's integrated "farm-to-fork" approach demands strictest hygiene standards as well as traceability for each stage along the production chain in order to minimize the danger of zoonosis is from the onset (Diels \& Thorun, 2015; EFSA, 2005). That also explains why the EU still bans the treatment of carcasses with chlorine compounds despite of its own food safety agency, EFSA, classifying the method in its own right to be harmless to human beings (EFSA, 2005). This comprehensive hygiene concept throughout the entire production chain-in particular the slaughtering process - is not mandatory in the US, where enterprises must exclusively verify the safety of their end product. That is why those entities' last production stage always resorts to chemical treatments to minimize the pathogen burden on carcasses (BEUC, 2014). The same ideology underlies Regulation (EC) 1831/2003 which prohibits the admixture of antibiotics to animal fodder in the European Union in view of the accretive occurrence of antibiotic-resistant bacteria. These agents are prevalently misused in the American meat sector for non-therapeutic ends, namely accelerated fattening of animals (Mellon, 2013). American agencies are afraid of other things instead. Kinder Surprise Eggs are forbidden in the land of unlimited possibilities because they contain "non-edible objects" which is ironically inherent to their very nature. Specific bacteria—which are 
classified as "natural" in the EU-are an anathema to Americans. The import of European raw milk cheese is suppressed since the US insists that milk must be categorically pasteurized in the process of cheese production in order to kill off any dangerous germs. The argument that some non-hazardous bacteria are essential for the cheeses' flavor is in this debate of secondary importance to American regulators. In summary, the US' and EU's divergent approaches towards risk management translate into a formidable dilemma in terms of concluding a transatlantic trade and investment agreement. This ominous situation got even more gridlocked when civil society groups constricted the Commission's room for maneuvering. By "appealing to the public about the possibility, however remote, of having to accept GMOs, chlorinated chicken and hormones (they forced) officials to repeatedly and publicly guarantee that EU standards would not change" (Eliasson, 2015).

Finally, subsidies are not only a central issue when it comes to blatant protection of one's own agricultural sector but embraces various business fields. The author firmly believes in this connection that the seemingly intractable WTO subsidy disputes around Airbus and Boing most certainly complicated TTIP negotiations.

\section{Government Procurement}

Another obstacle to overcome is the non-reciprocal market access in government procurement. The USTR (2013) might claim that the EU's Directive 2004/17/EC on procurement of utilities - covering government contracts in the energy, water, urban transport, and postal services sector-discriminates against bids with less than $50 \%$ domestic content. But most studies unveil that the US' procurement market is much less accessible than the European one since only $30 \%$ in comparison to $90 \%$ of government procurement in the US and the EU, respectively, is covered by the plurilateral GPA (Decreux, Milner, \& Peridy, 2010). European firms complain about the limited scope of market access to federal government procurement due to the Berry Amendment (10 U.S.C. 2533a) that restricts government purchases in certain fields to American firms for security reasons as well as the Buy American Act (41 U.S.C. 8301) that prescribes the preference for domestic goods and services in government contracting across the board. The constricted access to US government procurement markets at the sub-central-i.e., state and city - level is another thorn in the side of European officials since the 50 states are not bound to governmental procurement commitments laid down in US trade agreements. For example, only 37 states acceded voluntarily to the provisions of the WTO GPA in 1995 (Akhtar \& Jones, 2014).

\section{Investment and Services}

Furthermore, delegates probably quarreled over mutual market access with respect to investment. Although the US rolls out the red carpet for inward FDI in principle, non-domestic enterprises encounter ownership constraints in specific sectors - e.g., communications, maritime, aviation, mining or natural resources—under the pretext of protecting national security (Seitzinger, 2013). In this connection, additional market access barriers in the American "air and maritime transport market as well as the postal and courier services market, and professional services such as lawyers, architects, engineers, etc." (EC, 2013b) thwart the aspirations of corresponding EU based provider. While EU carriers for example are restrained to a maximum holding of $25 \%$ on an US airline, the US cabotage markets in air and maritime transport are even completely sealed off. Those impeding conditions so not hold true for American business on European grounds in reverse. In return, Americans criticize discriminatory entry conditions for foreign investors (Chase, 2011), exacerbated by even more rigorous practices regarding licensing requirements for market entry in some individual EU member countries (USTR, 2015).

To the displeasure of Brussels, Washington has been quite explicit about their intent to not only preclude 
transport and postal services but also financial services from a potential TTIP (Beck, 2014b). While the former issues could be sorted out conceivably, the US is utmost reluctant to incorporate any regulation on the financial sector into a bilateral agreement. In light of existing for a of global coordination such as the G20 or the Financial Stability Board, the US questions the meaningfulness of pronounced bilateral cooperation in this domain any how (Donnan, 2014). The European camp, in sharp contrast, calls for an attuned legislative response in the wake of the 2008 financial crises in order to prevent fragmented regulatory systems and proactively combat the dangers of reoccurrence (EC, 2014). It was bound to happen: The EU-US trade talks hit a roadblock over the tighter control of financial services. Worse still, the US's unilateral act of financial services regulation marked a move in just the opposite direction of joint cooperation. As Washington abandoned the principle of home-country regulation in finance in 2014, under which e.g., Deutsche Bank was regulated in Frankfurt, operative foreign banks are nowadays also amenable to the US authorities and obliged to hold reserves in the form of vault cash or deposits with the Federal Reserve (The Fed, 2017). This change in law has already provoked hefty fines for foreign entities on grounds of violating US sanctions against Iran or other purported "roguestates", even though their incriminated business interactions had by no means been proscribed by their actual home jurisdictions. This "Balkanization" of cross-border capital flows indubitably jars with the spirit of a single transatlantic economic space.

\section{ISDS}

Coming back to investment, investor-to-state dispute settlement (ISDS) transpired to be a highly controversial topic during TTIP talks. Investment protection is a central part of most trade agreements that warrants investors certain rights in the complementary country, such as property protection, free transfer of capital, and protection against discrimination. It involves the implementation of a dispute resolution process which enables foreign investors to directly sue the partnering country's government for compensation instead of indirectly seeking their very own government to espouse claims on their behalf, i.e., those foreign investors who find themselves at a disadvantage due to new regulations or laws in a host state are enabled to invoke their rights through ISDS. Many Germans still vividly remember the Vattenfall case, when the federal government decided to phase out nuclear power in the aftermath of the nuclear disaster in Fukushima. The Swedish energy giant thereupon filed a suit against the correspondingly obligatory decommissioning of its two local power plant sat an international arbitral tribunal. The group invoked the Energy Charter - an economic agreement for cooperation in energy matters between 54 nations - to vindicate their claim for damages over $€ 4.7$ billion. Critics profess a flood of these claims for damages in the wake of a trade accord equipped with an ISDS chapter (Holmes \& Dawar, 2016). It might create an unpredictable parallel justice and undermine governments' capability of regulating in the public interest on either side of the Atlantic. The investor community alleges that ISDS is imperative for bringing forward substantiated claims when being denied due process, discriminated against based on nationality, or expropriated of company assets (Eliasson, 2015). Opponents, conversely, question its raison d'être within TTIP given the already existing strong overall levels of EU and US investor protection (Akhtar \& Jones, 2014). Fearing that an ISDS chapter would thwart legitimate policy making because it provides companies with legal redress against democratic decisions through lawsuits in international tribunals, diverse civil society groups commenced to discredit ISDS via protests and policy papers from fall 2013 onwards (Eliasson, 2015). An understandably alarmed European Commission thereupon conducted an online survey on the disparaged arbitration bodies spanning over 150,000 participants in all member states whose large majority deprecated this 
practice (EC, 2015a). This impelled Cecilia Malmström in her position of EU Trade Commissioner to suspend the negotiations on ISDS for the time being in 2014 for the sake of public consultation. At the end of the day, the European Commission did not propose to remove ISDS per se from the TTIP agenda but stuck with the concept of settling transatlantic investor-state disputes through arbitration panels. Its 2015 Management Plan thus diplomatically stated the Commission's "aim to include provisions for an effective state-to-state dispute settlement as well as an effective and balanced investor-to-state dispute settlement (ISDS) mechanism in agreements which include investment protection provisions and in free-standing investment protection provisions while preserving our right to regulate in the public interest" (EC, 2015b). In late 2015, a hard-pressed Commission put a proposal for a reformed and more balanced ISDS under TTIP on the table, whose blueprint at least found its way into CETA. The initiative advocated for (BMWI, 2017b): (a) enshrining the right of governments to regulate in the public interest, not to be undermined by firms invoking ISDS arbitration procedures; (b) processing investor claims through investment courts which consist of publicly appointed judges, unlike in the past when judges were appointed by the disputants themselves; (c) transparent proceedings via public hearings and published submission; (d) a genuine appeal mechanism with a panel of publicly appointed judges. At the 12th round of TTIP negotiations in February 2016, however, US representatives neither consented to publicly appointed judges nor to the optionality of appeal hearings.

\section{Environment and Labor}

Various European stakeholders then again rebuff the harmonization of environmental and labor standards, which are viewed as generally stricter in the EU. While American trade unions were hoping that a transatlantic harmonization in form of TTIP would entail palpable improvements on their ends (Josling \& Crombez, 2013), EU representatives are most certainly not willing to diffuse their high level of labor and environmental protection and workers. In this respect, the Council of the European Union (2013) demanded that "the EU and Member States' laws, regulations and requirements regarding work and labor conditions shall continue to apply". The EU insists on its environmental standards, because there is the belief that the American environment regulation agency lags behind and has not considered many factors of importance in the modern world (Holmes \& Dawar, 2016).

\section{IPR}

Yielding concordance on certain IPR (Intellectual Property Rights) related issues poses a tremendous challenge. For example, the liability of ISPs (Internet Service Providers) for infringing content on their networks has already turned out to be a notoriously controversial topic during the ACTA (Anti-Counterfeiting Trade Agreement) negotiations. It provoked fierce debates on "how to balance enforcement of IPR in the digital environment with ensuring the free flow of information" (Akhtar \& Jones, 2014). Although both Western allies champion strong patent protection, gaps exists in terms of patent term extensions, patent linkage as well as protection of test data as a means of delaying or preventing the market launch of more affordable generics or biosimilars. Yet, geographical indications (GI) remain, above all, the hardest nut to crack. Unbridgeable differences had already surfaced during the TRIPS (Trade-Related Aspects of Intellectual Property Rights) negotiations and will most likely also exert a chilling effect on any prospective talks on a transatlantic trade and investment partnership. The resultantly weak TRIPS agreement merely obliges WTO members to warrant a minimum level of GI protection, i.e., to avoid unfair competition and deception of customers. Beyond this, the two parties' traditional concepts of protecting geographical indications could 
hardly be more different: Regulation (EC) 510/2006 enshrines the EU's elaborate regime of safeguarding its rich variety of geographical indications. It dictates that a designation of origin (PDO) is exclusively reserved for agricultural products or foodstuff whose entire "production, processing and preparation (...) take place in the defined geographical area", while a protected geographical indication (PGI) is awarded when at least one of the three stages had been performed in the defined geographical area. The US pursues a trademark regime on the other hand, where these kind of designations only label special product categories (Radauer, 2009). Conclusively, the trademark "Parmesan" could be conferred on any cheese on this planet which had been generated by the distinctive Parmesan manufacturing process. "Trade friction is often the result, particularly when EU geographical indications are used by US businesses not only on the domestic, but also on the world market" (EC, 2013b). Because protecting designations of origin is a high priority for the European side (Beck, 2014b), they are adamant about embedding provisions around GIs in a transatlantic trade and investment agreement. The "historically strong U.S. resistance to more expansive protection and enforcement of GIs raises questions" (Akhtar \& Jones, 2014) thus engenders an awkward predicament.

\section{Industrial Regulations, Standards and Conformity Assessment Procedures}

The author reckons the plethora of gaps in industrial regulations, standards, and conformity assessment procedures as yet another serious pitfall on the road towards TTIP. First of all, the author shall incisively explain these technical terms:

A technical regulation is a government document that lays down product characteristics or their related processes and production methods, including the applicable administrative provisions, with which compliance is mandatory. It may also include or deal exclusively with terminology, symbols, and packaging, marking or labelling requirements as they apply to a product, process or production method. (ITC, 2018)

Almost the same definition applies to standards, except that they are approved by a recognized standardization body and are most importantly, unlike the former, non-obligatory. A standard becomes mandatory, though, in case of being adopted by government bodies. Last but not least, conformity assessments procedures comprise testing, inspection, and certification.

The existing divergences in technical regulations are a thorn in the side of firms, notably the ones in key economic sectors, i.e., vendors of chemicals, pharmaceuticals, automobiles, machinery, and so forth. A prime example is the development of Regulation (EC) No. 1907/2006 concerning the registration, evaluation, authorization, and restriction of chemicals (REACH), when EU officials bluntly ignored American remarks that the nascent regulation would be incompatible with their Toxic Substances Control Act (TSCA, 15 U.S.C. $\S \S 2601-269)$ (Akhtar \& Jones, 2014). Their blatant disregard has entailed superfluous costs on both shores for testing, classification and labeling of export designated chemicals since its entry date in 2017. It lays bare the EU's notoriously insufficient public consultation, letting alone bilateral concertation when technical regulations and standards are amended or newly introduced.

Furthermore, a vast array of standards is shaped differently across the Atlantic despite of sharing the same ultimate objective. This circumstance primarily obstructs transatlantic trade of complex manufactured goods, consisting of innumerous individual parts which are subject to those diverse standards. This particularity holds true for an exasperated automotive industry, which is compelled to alternately adjust rear-view mirrors, wiper blades, headlights, rims, and many more components, when supplying both the European and the American market. What are the root causes of this dilemma? Firstly, it can be ascribed to the US' lack of harmonization 
with international standards (EC, 2013b). Another factor is the US's rather decentralized system of standard development, where several bodies set competing standards in the very same field without orientating on specific regulatory requirements in the first place regulatory agencies then select the ones that suit their objective the best (Akhtar \& Jones, 2014). The EU, on the other hand, formally recognizes attuned voluntary standards as an intentional vehicle for transcribing its legislative goals.

The differing approaches to conformity assessment procedures should not be neglected either. Testing in the US centers - apart from a couple of exceptions (e.g., drug certification and automobile emissions) —on manufacturers' self-declaration of conformity along with stringent liability, whereas the European system chiefly resorts to third-party certifications in regulated sectors (EC, 2018a; National Research Council, 1995; van de Zande, 2000). Only state accredited conformity assessment bodies (CABs), aka notified bodies, may perform these third party services inside and outside of EU territory in accordance with Decision No. 768/2008/EC. The EU, however, denies American entities the status of notified bodies. This is mainly because the US falls short of a centrally organized system of $\mathrm{CAB}$ accreditation and supervision, verifying the competence of those entities to perform essential services and certify to EU standards.

Another impediment is the inadequate upstream cooperation on draft standards and technical regulation, exemplified by REACH above. In brief, regulatory cooperation is the balancing act between facilitating trade and catering to both parties' regulatory objectives by exercising aspects of partnership and extensive organizational interoperability. Concisely, regulatory cooperation takes place in two forms as elucidated earlier, namely MRAs or harmonization of standards and rules across jurisdictions. It is crucial to comprehend that each method has its difficulties and benefits. Albeit, forming common standards is hardly accomplishable from a realistic point of view since each side will be reluctant to relinquish its authority to control commerce in the game of international relations. In any case, both players have been struggling so far to resolve their stern stands and ideological differences when determining the appropriate degree of regulatory cooperation in the context of a transatlantic trade and investment partnership.

Having recapitulated these plentiful aspects, the author concludes that an unconditional mutual recognition of each other's technical regulations, standards and conformity assessment procedures, letting alone a comprehensive harmonization, seems out of reach due to the divergent regulatory philosophies. The author even dare to suspect that one central prerequisite has not been met yet, namely mutual confidence in the negotiating partner's unfamiliar conformity assessment procedures, standards, and regulations. In fact, a series of previous rather fruitless bilateral exercises in regulatory cooperation at both sectoral and horizontal level corroborate my conjecture. The shortage of tangible results may also be partly blamed on the US agencies' high degree of autonomy and their sole accountability to Congress but not the executive branch with whom the Europeans actually had been collaborating with (EC, 2013b).

\section{SWOT Analysis}

\section{Internal Strengths}

For starters, the author will expand on the intrinsic strength of a deep and comprehensive transatlantic trade and investment partnership. This sort of agreement would undeniably mark a decisive step toward world-scale economic integration since the US in tandem with EU still account for an overwhelming half of world GDP ( $\$ 16,408$ billion and $\$ 18,569$ billion in 2016 , respectively) as well as a formidable third of global trade volumes (WTO, 2017b). 
As a matter of fact, the unique selling proposition of this transatlantic venture is that it would - unlike other international trade pacts which cover smaller geographic reach-erect the world's biggest FTA by bringing together the two economic giants. This in turn translates into a quantum leap in market size, offering firms of the signatory states to tap into enhanced economies of scale. These companies not only gain a competitive edge over excluded foreign firms but on grounds of falling unit costs and surging efficiency they are, by the same token, able to charge their customers lower prices, effectuating increased welfare. As companies expand into the partner's market, they may likewise convert their performance boost into profit generation to the delight of their shareholders. Whether through exports or foreign direct investment, these companies reach a greater market and make more revenues than before (Eurostat, 2018). A united market is also synonymous for intensified competition with all the attendant advantages for consumers and firms' efficiency. An EU-US trade and investment agreement would most probably entail a cost-optimized distribution of local resources for the US and EU member states to draw from. In effect, every participating country is poised to benefit from importing a larger segment of goods at cheaper costs and, at the same time, exporting increased quantities of those domestic goods where it holds a competitive advantage. This is in line with Winters (1999) whose basic theory of economic integration postulates that "provided the continents are not of very disparate sizes, negotiation of inter-bloc free trade would be mutually advantageous".

An implicit strength of the conceived treaty rests upon the mature markets it covers, implying that two populations are at ease when it comes to purchasing each other's goods and services. EU citizens have historically shown a disposition to accept American products and vice versa. Crucially, both economies are tightly intertwined which lay the ground for the largest commercial artery on earth (Fontagné, Gourdon, \& Jean, 2013; Müftüler \& Cihangir, 2012). Contributing to approximately one fifth of each total exports in goods, the two powerhouses denote their most important sales market to one another (WTO, 2017a). Expressing this in concrete figures, the US and the EU recorded reciprocal imports worth $€ 375.8$ billion and $€ 256.2$ billion in 2017, respectively (EC, 2017c). WTO (2017b) data moreover show that a staggering $30.9 \%$ of US's total exports in commercial services were directed into the EU while an overwhelming $35.3 \%$ of its corresponding imports originated from EU member states. The strength of these economic links is aptly captured in the following quote: "TTIP should not be branded as a 'revolutionary' deal—a scary word during times of insecurity — but as 'evolutionary,' building on the firm foundations of transatlantic trade and investment" (Gardner, 2017).

FDI actually reflects the real driver of the transatlantic relationship since approximately a third of the mutual exchanges consists of intra-company transfers (EC, 2017c). At the end of 2015, the United States had the biggest share (37.1\%) of the EU's FDI stocks abroad, whilst the US also consolidated with $41.4 \%$ its position as the preeminent holder of FDI stocks in the EU (Eurostat, 2018), valued at estimated $€ 2.7$ trillion and $€ 2.4$ trillion in 2016, respectively (EC, 2017c). The author expects that a TTIP would even intensify mutual FDI flows due to the erasing of various barriers to foreign investment and the necessary infrastructure that will protect the property rights of companies as well as enhanced dispute resolution mechanisms. Investment protection at all levels of government would be ensured through an independent and comprehensive investor-state and a non-competing inter-state dispute settlement system. Especially the investor-state settlement system should protect companies against unjustified state action.

In light of the already existing close trade and financial ties, it is perplexing that the thrilling prospect of a bilateral trade and investment agreement has not come to fruition yet. Given the already low average tariffs of 
around $4 \%$, the key to unlock these potentials truly lies in overcoming non-tariff barriers which mainly consist of customs procedures and behind the border regulatory restrictions. The greatest impetus of the deal is indeed expected from improved bilateral cooperation concerning regulations and standards, for example, by eliminating laborious duplicative conformity tests. Curiously enough, many industrial regulations and technical standards are set differently in the two jurisdictions despite of pursuing the same ultimate aim, exemplified by red turn signals in the US versus yellow ones in the EU. The deviating requirements inevitably inflict extra costs on manufactures - at times beyond the point of lucrativeness - as they are forced to modify their products accordingly. As TTIP holds out the prospect of MRAs, the same product would no longer have to be lavishly manufactured in several versions but would automatically receive access to the partner's market on the basis of "tested once" criteria, putting an end to cumbersome redundant testing. Improved regulatory compatibility in terms of technical standards, conformity tests, and registration procedures, which is central to a potential TTIP, would inevitably reduce unnecessary bureaucracy and save immense expenses to the benefit of American and European firms' competiveness. In fact, exporting companies incur $10 \%-20 \%$ of additional costs due to the administrative efforts and expenses for duplicative certification, conformity tests and registration procedures alone (BMWI, 2015). The entirety of NTBs can easily carry costs equivalent up to $80 \%$ of the invoice price (Hamilton \& Pelkmans, 2015). When a US manufacturer of light trucks meant to supply the European market, his model "required 100 unique parts, an additional \$42 million in design and development costs, incremental testing of 33 vehicle systems, and 133 additional people to develop-all without any performance differences in terms of safety or emissions" (Akhtar \& Jones, 2014). This example evinces that key sectors, such as the automobile, chemical, and pharmaceutical industry as well as information and communication technologies are, with good reason, desperately longing for this sort of regulatory alignment. Above all, it would benefit small and medium-sized companies on both shores of the Atlantic, which have often been unable to afford certification in the US and vice versa. Since not all regulatory divergences can realistically be overcome in one go, the TTIP was wisely envisaged as living agreement that allows for greater regulatory convergence progressively over time against defined targets and deadlines (EC, 2013a). Furthermore, it caters to the perspicuous need of installing a framework for improved consistent dialogue, consultation, and alignment when it comes to developing new regulation and standards in order to prevent future regulatory discrepancies in the first place. Once adopted and in force, they are empirically difficult to be removed or adjusted further down the line. Dialogue in its own right holds the potential for both regulators to establish the necessary mutual trust, learn from each other, and ultimately adopt the best of both worlds. For that reason, the author deduces - even though in dissent with the widely shared conception - that TTIP could yield improved standards and consumer protection even in Europe. Notably, the US is far ahead regarding safety of medical devices or public participation when mapping out new regulatory initiatives. What is certain: The present regulatory divergences block the economic potential of the transatlantic market place in numerous sectors.

With 3.5\% for the US and 5.2\% for the EU (WTO, 2018b), tariffs rates might be relatively low on average across the Atlantic. But given a daily trading volume of $€ 2$ billion, they still accumulate to a non-negligible financial burden for businesses, especially MNEs whose subsidiaries' operability relies on extensive intra-firm trade across both continents. Considering the magnitude of bilateral trade, the far-reaching removal of custom duties proposed in TTIP offers substantial economic gains. On top of that, multiple sectoral (agricultural products, beverages, textiles, shoes, cosmetics, trucks, etc.) tariff hikes still exists. SMEs are active in plenty of these areas, wherefore the author reckons them to join the ranks of TTIP beneficiaries. In those areas where the 
negotiating parties struggle to agree on outright tariff removal, the agreement would at least still simplify and harmonize customs clearance procedure. Reduced delays and transparent processes thus help to cut administrative costs and beef up the competitiveness of any American or European export orientated enterprise.

The author shall reiterate that SMEs suffer a great deal from the current tariff and non-tariff barriers to trade. The rather constant costs associated with red tape and TBTs carry more weight for them than for large companies owing to their comparatively lower export volumes. Summing up, the accompanying lifting of tariffs and non-tariff barriers, both quantitative (quotas, tariffs, etc.) and non-quantitative (import levies, subsidies, countervailing duties, etc.), signifies a pivotal intrinsic strength of a possible transatlantic trade and investment agreement.

In essence, the dismantling of tariff and non-tariff barriers to trade: (a) encourages companies, whether big or small, to pass ensuing cost savings on to their customers in form of discounted prices for goods and services against the background of increased competition. Lower commodity prices ultimately lead to more money in each individual's wallet, thus raising living standards; (b) results in a wider choice of goods and services from which European and American consumers are unnecessarily deprived of at present. This percolates through all aspects of life, from postal services to aviation and from running an errand to accessing the latest technologies and medical treatments; (c) entails higher remuneration of the workforce by increasing companies' profit margins, to be distributed amongst capital and labor; (d) creates analogously employment by filling companies' coffers for investment as well as facilitating mutual FDI flows per se. In this day and age, a myriad of high quality jobs is owed to a bunch of technology-driven EU companies whose subsidiaries operate in the US and vice versa. German based Siemens and General Electric with its headquarters in the US serve as role models in this respect, by dint of their affiliated foreign workforce hovering above 60 and 70 thousand staff on the other party's territory, respectively. With this in mind, the author concludes that an economic package would even ramp up the present level of transatlantic branching and demand for skilled labor. Maintaining the current status quo basically borders on a reckless failure to capture employment opportunities; (e) stimulates innovation between the two of the most advanced industrial and technology-driven economies by providing their companies with the optimal parameters to partner in research activities, transfer knowledge, share costs, and invent groundbreaking products. "In times where any budget-neutral source of economic growth is precious, the failure to harness the full benefits of trade and foreign investment must be considered an undesirable state of affairs" (EC, 2013a). Mildner (2015) aptly stated that every fourth job in Germany leans directly or indirectly on exports, in its industry even every second. In summary, welfare in the both economies is set to increase through higher earnings, rising employment, lower prices, and a greater product variety far beyond the ordinary supermarket shelf. TTIP is thus bound to achieve a heightened level of customer satisfaction, resting on discounted prices as well as an augmented selection of goods and services. These are exactly the messages which resonate with the public, especially when being delivered with eloquence and passion. The author is hinting at an efficacious communication strategy to garner the much-needed support of civil society when the bilateral talks are reanimated.

Furthermore, the treaty is expected to effectuate a level playing field for companies on both continents, particularly when participating in public tenders and applying for government contracts. For one thing, US taxpayers have to foot the bill of constrained domestic competition. What is more, non-discriminatory treatment is unambiguously in the interest of European entrepreneurs whose access to American government procurement is severely restricted at present. Speaking of competitive equality, another merit of TTIP is that it lays out the 
harmonization of the two sides' competition policy as such. Forms of state influence and privileges of individual companies, sectors, or regions are foreseen to be interpreted more broadly. Inversely, legitimate exceptions are to be defined more narrowly. This concerted action would render it more difficult to circumvent competition rules and serve as a prototype with global relevance. Beck (2014b) appositely affirmed that TTIP would oblige state enterprises to commercial orientation beyond their relevant tasks and prohibit cross-financing in non-monopolized markets. Besides, reciprocal constraint on subsidies also offers the chance to finally settle the gridlocked Airbus-Boing dispute out of court.

Other incentives in favor of a TTIP are strengthened intellectual property protection (e.g., selective legislative alignment of patent law) as well as better mutual market access for services. The treaty is ought to facilitate the posting of staff (e.g., for maintenance and repair of machinery), hand in hand with the interrelated recognition of professional qualifications of service providers (e.g., auditors, engineers, IT specialists, lawyers, accountants, architects, etc.). In the absence of such mutual recognition,

\footnotetext{
individual service suppliers must apply to an individual regulator at state level for approval on a case-by-case basis in order to have their particular qualifications recognized in that jurisdiction, a time-consuming and expensive process which acts as significant deterrent to the provision of these services on a transatlantic basis. (EC, 2013a)
}

We should not neglect TTIP's upside for third countries either. Flourishing trade between the two Western allies should in actual fact invigorate worldwide trade altogether because global value chains intertwine both economies with other economic regions more pronouncedly than ever before. In addition, higher incomes for European and American households thanks to TTIP will not only unleash a higher demand for goods and services produced in the infantile free trade area but also from elsewhere in the world. The author consequently infers that a TTIP-mediated surge in transatlantic trade would simultaneously engender employment, higher wages, and prosperity in third countries. This assertion of mine is substantiated by Francois (2013) from the Centre for Economic Policy Research (CEPR) whose empirical study projects a collective GDP growth of up to $€ 99$ billion to accrue in the rest of the world from positive spillover effects.

Speaking of CGE (Computable General Equilibrium) models - a class of economic models that leverage actual economic data to estimate how an economy might react to changes in policy, technology, or other external factors - the author shall not omit to illustrate their quintessential findings. Whether conducted by Berden, Francois, Thelle, Wymenga, and Tamminen (2009), Francois (2013), Fontagné et al. (2013), or Felbermayr (2013), the leading empirical studies on TTIP send a clear message by uniformly predicting an unequivocally positive economic impact on trade and real income for both partners. Resorting to virtually the same data base (GTAP 7 and 8) and closely related methodological designs, the first three CGE analyses report fairly congruent results. Francois (2013), whose work was officially commissioned by the European Commission, prognosticated that a comprehensive and ambitious FTA (reference scenario: nearly complete tariff removal and $25 \%$ reduction of NTBs) could trigger an increase in bilateral EU and US exports to the tune of $28.0 \%$ and $36.6 \%$, respectively. Apart from these significant trade creating effects, his renowned CEPR study estimates an increase of $0.4 \%$ in US GDP and $0.5 \%$ in EU GPD per year. It is imperative to understand that those estimates refer to additional annual increments over a simulation period of 10 years as compared to a baseline scenario without TTIP. This percentage figure amounts to an absolute additional GDP growth of $€ 119$ billion or an extra $€ 545$ income for an ordinary four-person household in the EU specifically. On the assumption of constant employment, the predicted supplementary increase in real wages of $0.51 \%$ per year-as 
compared to the benchmark scenario without TTIP-follows the same rationale: Firms' spike in productivity results in higher compensation for labor. The Bertelsmann study is in this sense distinctive for taking employment effects into account as well. Its author, Felbermayr (2013), forecast the creation of not least than one million new jobs for each party in his deep liberalization scenario. Finally, the author recapitulates that the implementation of TTIP would resonate with the long standing and progressively tightening commercial and investment relationship across the Atlantic by removing remaining barriers against trade and FDI.

\section{Internal Weaknesses}

Having elaborated on a series of pros, the author shall, in the spirit of impartiality, now expound potential weaknesses of a comprehensive transatlantic trade and investment agreement.

The author fears that even the strongest TTIP proponents would have to concede in retrospect that its actual effect on economic growth and job creation did not met their auspicious forecasts after all, because the inimical implications of preferential trade had not been properly accounted for in the first place. The author was truly struck that the role of rules of origin (RoOs) has either not featured sufficiently or has even been completely disregarded in the aforementioned empirical studies. As illuminated in Chapter 4 of this thesis, FTAs - unlike customs unions - allow for different external tariffs, which is why they resort to RoOs in order thwart the channeling of third country imports via the lowest rate member state as a gateway. Since RoOs are therefore ordinarily defined by a minimum threshold for local production and content, firms within the FTA are compelled to meticulously document the origin of their goods in order to merit the coveted preferential tariff treatment. The prima facie desirable tariff waiver is hence accompanied by considerable administrative efforts whose costs obviously tend to hurt SMEs the most. Depending on the dimension of restrictiveness, the RoOs entrenched in TTIP could at the same time deter European and American businesses from leveraging lower-priced third party inputs against the spirit of cost-optimized global value chains. Hence, some companies might ironically even opt to pay the corresponding applied MFN tariff when entering the partner's market instead of catering to a cumbersome RoOs regime for reasons of tariff exemption. The author's trains of thought resonate with Dieter (2014) who portrays cases where it is less expensive for companies to simply pay the levied duties than preparing certification of origin. Notably, he estimates the expenses for the latter at around $5 \%$ of the goods' intrinsic value and doubts against the background of the moderate average transatlantic tariff rates the economic benefits from their abolition in the wake of a TTIP.

The much vaunted overall positive impact of TTIP on total exports furthermore conceals sizeable trade distortion effects (Beck, 2014a). Firstly, cheaper imports from the US could curtail the magnitude of intra-EU trade through displacing products and services that were previously exchanged within the EU. Fontagné et al. (2013) suggested that the anticipated rise in overall EU exports would indeed be limited to $2.3 \%$, as compared to a 7.6\% surge when the effect on intra-EU trade is neglected. Francois (2013) similarly demonstrated that depressed trade among EU member states weighs gravely on the continent's total export performance as his prognosticated $€ 72$ billion decline of intra-EU trade has to be deducted from the heightened exports to the US and the RoW (€187 billion and $€ 33$ billion). Secondly, Felbermayr and Larch (2013) pointed to various scholarly studies which identify trade diversion effects to the detriment of third countries in the aftermath of bilateral trade agreements. Firms from those third countries, unlike the enterprises within the newly formed FTA, obviously forfeit a certain degree of competiveness due to the persisting tariff driven surcharges on their products as well as NTBs. Felbermayr (2013) congruently predicted that trade between the EU and BRIC 
nations would decrease by a tenth and between the US and BRIC countries by as much as $30 \%$. It is easily conceivable that the poorest developing countries in particular would be negatively affected because their market shares in these destitute nations' vital sectors are likely to shrink once the free trade agreement is adopted. Textiles are more than anything an integral part of their export industry due to unparalleled low production costs at the expense of low wages and poor working conditions. Hence, these exports could possibly decline once the removal of tariffs and non-tariff barriers would render textile trade across the Atlantic more lucrative. As a matter of fact, Janker (2015) speculated that TTIP would impel workers in developing countries to manufacture textiles even cheaper than nowadays in order to safeguard their firms' competitiveness. The author shall, however, put this bleak picture into perspective as the scholarly research by Francois (2013) and Fontagné et al. (2013) dissentingly projects that third countries would in sum capitalize on TTIP owing to positive spillover effects.

Without knowing the concrete contractual arrangements of the potential transatlantic trade and investment agreement, it is in the author's opinion difficult to predict whether economic losses would materialize for excluded countries. The WTO's (2016) remarks in this respect that third country producers would rather benefit from a deep and comprehensive TTIP than a tariff-only FTA because its anticipated regulatory alignment would play in favor of their cost structures vis-à-vis both American and European markets. Whereby this hinges decisively on whether the approach towards regulatory alignment is deliberately discriminatory or not. Third party suppliers do de facto not derive any advantage from the substantive provisions of a comprehensive PTA-e.g., mutual recognition or the containment of regulatory discretion-if it does not extend non-discriminatory treatment (most favored nation and national treatment) to RoW countries as well.

Besides, it is imperative to comprehend that each manner of bilateral regulatory alignment, whether harmonization or mutual recognition, features its own difficulties. Harmonization of standards is hardly accomplishable, because in the concept of the international relation each side is inherently reluctant to waive its authority to navigate commerce. Meanwhile, mutual recognition of existing standards does not necessarily engender an universal international standard to which third countries like China can adhere to. Apropos, the exclusion of China and other large emerging economies from trade regulation processes might pose an earnest problem in its own right. Firstly, the mega-regional project could be seen a stumbling block for multilateralism, acting as surrogate for a homogenously liberalized world trade system. Secondly, the underlying assumption that those rising powers are prepared to accept rules from whose formulation they have been excluded might turn out to be a fallacy because of those countries' growing weight and self-esteem. As the nascent RCEP (Regional Comprehensive Economic Partnership) embeds a host of these latter nations, TTIP could provoke hardened fronts between the two colossal trading blocs in tandem with the only too well known adverse economic and political ramifications.

Speaking of hardened fronts, it transpired that the two Western allies have already struggled to thoroughly harmonize or mutually recognize regulatory standards amongst each other, letting alone the involvement of third countries. As elucidated in Subchapter 7.4, the Europeans have, inter alia, no trust in American consumer protection whereas the US questions for example European healthcare standards. While it is certainly true that European standards are in many respects stricter than American, there are definitely singular domains where, sure enough, the opposite applies. A myriad of chemicals is permitted for use in European cosmetic products in contrast to only a few carefully selected ones on American territory. TTIP opponents are consequentially apprehensive of a race to the bottom under the pretext of harmonizing standards and establishing common rules 
(Kahn et al., 2015). Although the European Commission has taken pains to assuage concerns, opposing voices still assert that FTAs commonly usher in a watering down of standards on both ends when compromising on the least common denominator in form of the weakest or most business-friendly standard in each case. Apart from industrial regulations and product standards, this could possibly also affect other policy areas, such as protection of consumers, workers, and the environment. Solely the culture and media sector were excluded from the negotiation mandate by the European Parliament. The notion of a minimalist compromise is in actual fact not too far-fetched since both parties' matching economic clout logically implies that neither of them is empowered to prevail and dominate the negations.

GMO crops, chlorinated chicken and hormone-treated meat are only some of the many sensitive topics that have aroused great anxiety in European press coverage and public platforms around agriculture and foodstuff. Verily, there is a whole raft of contentious issues about sanitary and phytosanitary rules. The crux of the matter lies in the fundamentally dissimilar regulatory philosophies towards risk management across the Atlantic. As profoundly demonstrated in Subchapter 4.1, the Europeans' prevalent precautionary principle prescribes that products may not enter the market unless any deleterious effects upon consumers can be ruled out with certainty, while potentially harmful products are only withdrawn from the US market once their health risk has been evinced. In this connection, Rudloff (2014) indicated alternative approaches to harmonizing the exceedingly divergent food standards between the US and the EU. Apart from mutual recognition, she illustrates the possibility of adopting non-discriminatory labeling requirements. Either way, it will undoubtedly be a Herculean task to reconcile the two utmost divergent regulatory philosophies and yet genuinely appease both sides with a sustainable solution. It is imperative that both camps of negotiators can wholeheartedly take a stand for the settled compromise and sell it to their affiliated delegates and electorate. Or else it is not worth the paper it is written on with regards to implementing and properly enforcing the deal.

In addition, European trade unions dread that TTIP could lead to a deterioration in workers' rights and labor standards, as the US has only ratified two out of eight core labor standards of the International Labor Organization (ILO) so far (Esslinger, 2014). American trade unions, on the other hand, endorsed TTIP as they were hopeful that it would contain a mechanism to foster the implementation of the entire range of these ILO core labor standards (Josling \& Crombez, 2013). Along the same lines, there are worries that an agreement would undermine high European standards in the field of privacy and environmental protection (Kolev, 2016). This anxiety has certainly everything but soothed by several recent cases in the US where the privacy of customers and companies was breached.

Considering Washington's and Brussels' conflicting positions on sheer multitude of regulatory subjects, negotiations might easily produce a kind of package deal where in the spirit of quid pro quo, a partial victory in one specific area will have been dearly bought with tremendous concessions in another area. Diels and Thorun (2015) reasonably suspected that fundamental standards of labor, environmental and consumer protection could fall by the wayside as a consequence.

A lack of transparency did certainly not help to placate the widespread public concern either. In Germany, for example, it has even been difficult for parliamentarians to retrieve information about the progress of the negotiations for a long time. The German Federal Government merely provided access to Commission documents, such as position papers and status reports on the negotiation rounds. Interestingly, the US set up reading rooms in its European embassies which disclosed minutes of the proceedings and also reflected the American position. At times, only government officials were granted access. Members of the Bundestag have 
only been allowed since 2016 to inspect this sort of classified documents in a reading room in the Federal Ministry of Economics and Technology. Despite of the limited insight, literally nothing was supposed to be leaked to the public. The conduct of negotiations behind closed doors is a tremendous deficiency because it fuels the suspicion that preference is being given to the interests of corporations and investors. The general populace most certainly took little comfort in the fact that a couple of delegates were permitted to view transcripts in dedicated reading rooms or that position papers were published on the Internet prior to each negotiation round. The impression of a corporate agenda already manifested itself when both parties were drafting their negotiation positions. Trade unions and civil society organizations merely had an astonishingly marginal presence in this process, if at all (Beck, 2014a). From an objective perspective, we cannot rule out either that corporate would on no account fall victim to some of the newly stipulated provisions.

While the lack of transparency and public participation are in principle remediable at a conceivable relaunch of the bilateral talks, the agreements partly restricted legislative reach on primarily the American side is not. Any possible alignment on industrial regulations, standards and conformity assessment procedures is meaningless, if not firmly implemented. Preceding horizontal and sectoral agreements have been of no avail due to US federal agencies' high degree of autonomy and sole accountability to Congress instead of the executive branch, with whom the European Commission had essentially been bargaining. The Europeans should evidently question the ability of American Department of Commerce to submit those mighty federal agencies like the FDA to any changes that would restrain their authority to regulate. Having centralized all conformity assessment functions under one roof, these federal agencies understandably prefer direct and autonomous cooperation with creditors on the old continent to being directed by governments. The author may similarly query the PTA's legislative reach in terms of public procurement, not only due to the US's overriding Berry Amendment and Buy American Act but also its limited influence on the decision making processes at the sub-federal level. The strained national budgets in the US and many European countries should not been forgotten, either. Any deal struck might eventually not be adequately implemented, monitored, and enforced due to insufficient financial and personnel resources allocated to the respective responsible actors in administration, legislature, and judiciary.

As TTIP foresees to open up the public sector apart from a few exemptions (Fritz, 2014), it will propel the process of privatization. Since the latter tends to subvert collective bargaining, Schmelzer-Roldán (2014) contended that especially less skilled workers would thereupon suffer income losses or face harsher working conditions. The PTA could similarly assist big companies in overpowering smaller ones. Since a larger market creates more room for scale economies to unfold, a wave of mergers and acquisitions will be likely to ensue. Will SMEs still cope to withstand the stiffened competition unless they command a technological lead? Especially the envisaged lifting of tariffs and NTBs in the agricultural sector puts the existence of small farmers in Europe at stake as they are simply not able to compete with the dumping prices of American large scale producers. Intriguingly, even fervent TTIP advocates like Bureau, Disdier, and Emlinger (2014), who conceded job losses for smaller farms, confirm this hypothesis of mine.

ISDS signifies in the author's opinion an Achilles' heel of a potential transatlantic trade and investment partnership. Incorporated for the very first time in a bilateral trade agreement between Germany and Pakistan in 1959, its original intention was to encourage foreign investment by protecting investors from discrimination or expropriation (The Economist, 2014). Industrialized nations are understandably reluctant to renounce such handy clauses when dealing with less developed countries whose judicial and legal systems appear not to 
provide sufficient investment protection. Arbitration proceedings between investors and governments have therefore already been conducted for decades. At present, 2,900 bilateral investment protection agreements are in place worldwide but it is highly questionable whether ISDS is truly indispensable in an agreement between two parties with such sophisticated legal systems (Draper \& Freytag, 2014). Especially recent cases, where multinationals like Philip Morris and Vattenfall leveraged arbitration tribunals to act against unwelcome legislation, such as anti-tobacco laws or nuclear phase-out, have brought ISDS in disrepute. Those corporations have deliberately exploited fuzzy definitions of expropriation to claim compensation for lost profit due to changes in government policy that have happened to harm their business. Critics have increasingly doubted the democratic legitimacy of private arbitration, denouncing it as an opaque and arbitrary parallel justice. These claims are adjudicated by private lawyers before international arbitration tribunals, whose rulings are non-appealable and directly enforceable (Dietrich, 2014). Furthermore, this special cause of action creates legal asymmetry because it is exclusively entitled to foreign companies but not domestic ones, which can merely recourse to common courts of law despite of being confronted with the same situation when sustaining revenue losses due to a change in government policy. This arrangement effectively evokes a parallel legal system and bestows the power upon foreign corporations to straightforwardly challenge democratically enacted new legislation. The laudable idea of investment protection could thus massively backfire in the context of TTIP by undermining government's legitimate sovereignty to regulate in the public interest. As already reasoned in Subchapter 4.4, it could elicit both a surge of arbitration proceedings across the Atlantic and a regulatory chill. Legislators might cease to lay down new laws in favor of workers, consumers, and the environment in order to spare taxpayers of being saddled with possibly ensuing corporate claims for compensation. The author is afraid that it is virtually impossible to find the right balance between sufficient investor protection on the one hand and unobstructed political sovereignty on the other, preventing multinationals to abuse concomitant investor-state arbitration when a government for examples introduces a minimum wage or raises the latter. Again, the author conjectures that ISDS has become so controversial that it threatens to scupper any future transatlantic trade and investment agreement. If any, the more balanced and more transparent variantà la CETA would stand a chance of ratification.

Besides, there is also a question mark hanging over the treaty's government-government dispute settlement mechanism. It is unclear whether the latter would be chosen in case of a dispute or the WTO's coexisting platform. In a worst-case scenario, an extreme situation could arise, where the WTO and TTIP for a issue conflicting decisions. Either way, it undermines the WTO's esteemed settlement process and weakens the organization as a whole. Mega-regionals alike the TTIP are of course in this context particularly problematic. By serving predominantly geopolitical as well as commercial objectives, a PTA undercuts per se the ideal of multilateral trade liberalization (Dieter, 2014).

\section{External Opportunities}

We shall now dwell on external opportunities which could prompt a resumption of the bilateral talks and culminate in the conclusion of a transatlantic trade and investment agreement after all.

The EU's and the US's combined contribution to global economic growth has fallen from around $50 \%$ to around $15 \%$ in recent decades (Cieschinger, Demling, \& Kuepper, 2016). While still signifying the most important export destination to each other, the share in each other's imports has furthermore been steadily declining during the post-millennial period (WTO, 2017a). China as an example par excellence has become the 
EU's fastest growing export market whilst the US's increments in trade with ASEAN (Association of Southeast Asian Nations)-Plus-Three nations have along the same lines out performed those with its Western partners over the last decade. The major driver of this declining trend can in all probability be attributed to the coinciding rapid rise of predominantly Asian NIEs (Newly Industrializing Economies), whose enhanced competitiveness, output and export volumes have changed the structure of world trade flows (EC, 2013b). Founding the world's largest FTA thus offers both parties a golden opportunity to curb this drift and to counteract the attack on their supremacy on the economic front. Without it, the relative size of the transatlantic pole is bound to dwindle in the world economy.

Both trade agreements with Korea and other recently signed FTAs with South-East Asian states (e.g., EU-Singapore Free Trade Agreement) have certainly reinforced this trade distortion away from the transatlantic trade relationship. Albeit the newly elected Trump government immediately pulled out of the anticipated TPP, the sudden diplomatic approval on the main elements of JEFTA (Japan-EU Free Trade Agreement) on 6 July 2017 indicates that this trend is nevertheless likely to continue (Burchard, 2017). As a matter of fact, Washington and Brussels increasingly run a latent risk of being disadvantaged in each other's market in the absence of their own bilateral FTA in light of the rising number of PTAs that each one has installed with other nations. The US for instance remains the only NAFTA signatory which the EU has not entered into a PTA with. In particular the EU's latest landmark agreements with Canada (CETA) and Japan (JEFTA) could provoke the administration in Washington to resurrect the bilateral talks with Brussels in order not to be left out and fall behind. A trade accord hence represents a geostrategic opportunity for both giants to access each other's huge sales markets with all the attendant macro-economic benefits. Against the backdrop of high public debts and strained national budgets, the prospected growth in exports, GDP and wages should be a compelling incentive to relaunch the negotiations for either of the nations involved, chiefly for various crisis-struck European countries.

A bilateral PTA also holds out the prospect of significant gains at the sectoral level (WTO, 2016). Key industries, such as automotive, medical devices, chemicals and pharmaceuticals would derive great advantage from the facilitation of customs procedures as well as the envisaged regulatory alignment on technical standards, conformity tests, and registration processes. As reasoned in Subchapter 5.1, this applies to both MNEs and SMEs. The latter are often prevented from exporting across the Atlantic because their lower turnovers relative to big businesses do not recoup the incurring expenses for complying with costly TBTs and bureaucracy in the first place. The present NTBs impair the efficiency of MNEs at the same time, considering their deeply fragmented value chains and excessive intra-firm trade between subsidiaries. In a nutshell, the author may deduce that the reinvigoration of a transatlantic trade and investment agreement enjoys strong support from various highly influential business lobbies on either side of the Atlantic. Some of these have privileged access to the USTR and the European Commission, i.e., the perfect platforms to express their high hopes of what a comprehensive agreement could achieve (CEO, 2013).

If that was not enough, the notion also receives the full backing of several think tanks and liberal public interest groups, e.g., the Initiative Neue Soziale Marktwirtschaft in Germany, whose 2016 promotional dossier praises TTIP to the skies. While most proponents typically extol the abundant economic benefits of the trade pact, the author personally feels that they have so far missed out on the chance to resolutely present its intended sustainability chapter in a positive light in the public discourse. This strategy would certainly go down well with citizens in times of perceptible climate change. Environmentalist and conservationists could similarly be won over by the prospect of propelled eco-innovation. Eco-innovation aims at mitigating the anthropogenic 
environmental impact and a more sustainable usage of resources. In other words, the concept involves the development of sustainable products, techniques, services, and processes through the commercial application of scientific knowledge in order to make efficient use of limited resources and elicit ecological improvements. By upgrading their efforts towards more sustainable and efficient manufacturing, business entities would not only live up to their social responsibility but reap a competitive edge at the same time. The only question remaining is whether opinion leaders are savvy enough to laud the anticipated sustainability chapter of a comprehensive trade agreement as an effective instrument to move towards a green economy and combat global warming.

Another beacon of hope is the positive attitude of the European Commission towards the revival of the transatlantic undertaking. De Ville (2013) pertinently pinpointed the conclusion Uruguay Round in 1993 as a watershed moment, when advocates of free trade gained the upper hand over the protectionist faction in Europe. CETA and JEFTA are in this context unequivocal signs that Brussels has maintained its affirmation of free trade throughout. Hay (2007) and De Ville (2013) sagaciously suggested that the Commission deliberately harnesses this liberal trade policy to justify structural reforms of the internal market. "Global Europe-Competing in the world" and "Trade for all", the Commission's 2006 and 2015 trade policy strategies, respectively, explicitly confirm the link between external market opening and internal market reforms. The latter are directed to dismantle "unnecessary" national regulations with the intention to integrate markets and boost European firms' competitiveness (De Ville \& Orbie, 2011; Siles-Brügge, 2011). We may conclude that the Commission is willing to make a renewed attempt at TTIP because a comprehensive agreement would function as a catalyst for deepening the single market and disciplining reform-reluctant actors within the EU.

When speaking of market integration, we shall be reminded of a certain dissident member state where just the opposite is currently unfolding. Let us just assume for a moment that the accusations of some British propagandists are correct and the EU truly wants to cold-heartedly punish the UK for Brexit as a demonstrative deterrent for any other member state to jump on the bandwagon of exiting the union. Facing the gloomy outlook of having to leave the prosperous European Common Market, the British government has already announced to reinforce its economic bonds beyond the old continent instead. More precisely, the cabinet has placed a high priority on entering into a FTA with the US. Ironic as it may seem, this could even spur the EU's aspiration to relaunch its very own trade negotiations with the US. The author is convinced that the UK's competing endeavor has incited the Commission to showcase its capability of achieving quicker and better outcomes by virtue of the block's economic clout and consolidated bargaining power in comparison to a single renegade country which has to queue up at the end of the line and budge only too often when dealing with an economic titan like the US.

The White House might likewise be driven by political calculus towards a deal. Would it not be an excellent occasion for President Trump to appeal to his electorate and portray himself once again as a "great" deal maker? $\mathrm{He}$, who condemns the EU's trade surplus, could sell a deal under his charge as an agent to reduce the US's trade deficit. It is certainly not foolish to believe that he would succumb to the temptation of claiming to have fulfilled one of his core campaign pledges by bringing about more balanced and reciprocal trade with the EU. Frankly, the real estate tycoon would not be too wrong after all. An ambitious removal of import duties and NTBs would indeed boost US exports in industrial goods, services, and agriculture (Fontagné et al., 2013).

With a raft of retaliatory measures (drastic EU tariffs on agricultural goods, Harley Davidson motorcycles, jeans and bourbon, etc.) and counter-retaliatory measures (25\% US import duties on European cars) on the horizon, the looming EU-US trade war over protectionist American steel and aluminum tariffs could, albeit ironically, pave the way for a reopening of TTIP negotiations. It was end of July 2018 when US President Donald 
Trump and EU Commission President Jean-Claude Juncker in fact reached, at the 11th hour, an understanding to avert the impending trade conflict and impose for the time being no further new punitive tariffs (von Petersdorff, 2018). Trump spoke of a big day for free trade and Junker told reporters in Washington more prosaically in response: "I came for a deal-we made a deal" (The Guardian, 2018). A working group was subsequently assigned to explore how both parties could eliminate tariffs on industrial goods and facilitate trade in chemicals, pharmaceuticals, medical devices and services (Crolly, 2018). While the actual source of contention around steel and aluminum tariffs is supposed to be sorted out, the threatened tariff hike on European automobiles is off the table as long as those talks are on. In the author's opinion, an EU-US trade agreement is not only an expedient vector for burying the current tensions but also for resolving those long-standing transatlantic trade disputes (see Chapter 6 for more details) and for forestalling future ones. At the end of the day, it is consumers who have to foot the bill of these conflicts, wherefore it would be regrettable not to astutely exalt TTIP's defusing effect in future promotional campaigns.

Anyway, hopes are high this time because the notion is supported by key stakeholders across the Atlantic. Senior politicians of the US administration have signaled their interest in reviving the bilateral talks on a FTA (Spiegel, 2017). When US Commerce Secretary Wilbur Ross addressed a Berlin audience in June 2017, he told delegates that President Donald Trump was receptive to talks on TTIP to resume. His speech was not short of personal conviction, either: "I stand before you tonight to say this in a more explicit fashion: we, as major trading partners of each other, should have a free trade agreement" (DW, 2017). In March 2018, Ross stated amid the EU-US trade dispute: "He (President Trump) terminated the trans-Pacific deal; he didn't terminate TTIP. That was meant quite deliberately and quite overtly as a message that we're open to discussions with the European Commission" (Bravo \& Chatterley, 2018). The expected positive macro-economic effects could particularly mean for those austerity-struck EU countries a blessing in disguise. The influential German Chancellor Angela Merkel is moreover a staunch advocate of free trade and has repeatedly spoken out in favor of recommenced efforts towards a free trade agreement with the United States (Sueddeutsche, 2017). Peter Altmaier, herloyal Federal Minister of Economic Affairs, already pleaded in the beginning of May 2018, long before the amicable Trump-Junker meeting, for converting the quarrel over American steel and aluminum tariffs into a launching pad for wider trade talks (Stratman, 2018). The author suspects that the Monsanto takeover in 2018 will even bolster Berlin's endorsement because the acquiring German industrial giant Bayer will now join forces with the powerful lobby in the US, pushing to penetrate the European market with GM crops. Hence, the $\$ 66$ billion business coup has unwittingly increased the odds of trailblazing European concessions on this contentious issue. The author can quite imagine a face saving compromise, where the Americans give in on the demanded GMO labeling requirements in return.

Staying with regulations: The integration of the two economic zones to create the biggest FTA on earth would not least consolidate the US's and the EU's influence on international commerce. As the global economy progressively evolves in the direction of a multipolar world order, a comprehensive trade and investment agreement might epitomize the last chance to put their stamp on 21 st century global trade. With its focus on rules and regulatory convergence, they could seize the moment to impose their jointly formed provisions on the rest of the world. Due to their combined colossal economic weight, third countries would feel obliged to adhere to their newly established framework in order to not miss out on placing products on either of these hugely profitable markets. By exerting this intense pressure for adjustment, the two Western allies could adroitly harness their united sway to open up foreign markets for their very own companies. Aside from the desire to shape the 
rules of the global trading system, there are also other geopolitical motivations which, inter alia, relate to the US's goal to curtail the mounting global influence of Beijing and inhibit the emergence of a China centered economic bloc in East Asia (Ghibutiu, 2015; Yong, 2014). Subramanian and Kessler (2013) contended in this connection that a TTIP would not only force China to abide by the aligned transatlantic rules and regulations but would most importantly preempt Beijing from doing so the other way around. With their fading political and economic clout, time is of the essence, as Peking has already started to contest the Western partners' ability to decide on the fate of global governance(Hart, 2010).

Notably, both are equally united in rebuking the vast array of anti-competitive practices of China and some other emerging countries. Those encompass unfair SOE activity, localization barriers to trade, patent infringement, breach of copyright protection, and trade secret theft— just to name a few. The latter alone afflicts vulnerable European and American MNEs, whose business model relies on operating in those countries, with millions of euros in damages from forfeiting their technological edge (Liu \& Self, 2012). It goes without saying that restraining the aforementioned inequalities — by collaboratively formulating new globally relevant rules on these WTO+ and WTO-X trade policy issues - is of mutual interest. In doing so, they would break new grounds and raise the bar in these disciplines for the rest of the world to follow. This bears great potential to strengthen the normative underpinnings of the multilateral system through setting benchmarks and delivering templates for future liberalization rounds under the WTO. A Western alliance should in fact be acknowledged as an appropriate vehicle to resolve any controversial issues, where progress at the multilateral level would be far harder to achieve, not least because of the sizeable concession demanded by some developing nations. Due to its compelling nature, a bilateral consensus on those key trade and investment issues would inarguably assist in bridging the current impasse in the Doha Round about which the EU and the US are so appalled of. Schott (2013) pertinently argued that an amicable commitment to cap domestic agricultural subsidies would not only aid strained national budgets but also set a precedent for a broader multilateral deal, providing fresh impetus to WTO negotiations where this kind of quid pro quo is required "to unblock long-stalled efforts to liberalize manufactures and services trade". The persevering deadlock consequently unveils the dire need to reinvigorate TTIP as a stepping-stone for multilateral trade liberalization.

Last but not least, the latest turmoil in international relations could possibly even play out in favor of a TTIP revival. A show of Europe's solidarity in both economic and political terms would just come at the right time for the US, while waging a destructive trade war against China. It would analogously convey a long sought-for sign of unity from a foreign policy perspective in the light of the two NATO partners' resentment over Russian aggression, namely the annexation of Crimea, the Skripal poisoning in Salisbery and the blatant military support of Assad forces in the Syrian war.

\section{External Threats}

The author shall finally discuss external circumstances which threaten the resumption of the TTIP negotiations and could therefore strike a deadly blow to the vision of a comprehensive transatlantic trade and investment agreement. Please note that the TTIP's multiple points of contention in Chapter 4 are attributed to the parties' engrained opposing positions on several issues. Being immanent to the transatlantic venture, they were partly reflected in Subchapter 7.5.2 as internal weaknesses, e.g., the constrained legislative reach of the potential treaty due to overriding domestic regulatory structures (independent Federal Agencies), national laws (Berry Amendment and Buy American Act), or limited legal force on the sub-federal level. Thence, they are not going to 
be reiterated in the following.

A verily external threat is, however, the impressive mobilization of civil society groups against the treaty in both jurisdictions. The initiative StoppTTIP! (2018) is an example par excellence, being purportedly "supported by an alliance of more than 500 civil society organizations and trade unions from all over Europe". Attributed "to its focus on regulatory coherence and cooperation in various sectors, TTIP was bound to raise concerns, even strong emotions, about countries' sovereign right to regulate, as well as their way of life and their health and safety standards" (Gardner, 2017). European environmental and consumer groups had already began campaigning against the envisaged regulatory alignment when the negotiations were kicked off. From then on, they have been unrelentingly propagating that mutual recognition and regulatory convergence of standards across the Atlantic would shatter the hard-fought achievements on food safety, worker rights, and environmental protection (BEUC, 2014; Josling \& Crombez, 2013; Josling \& Tangermann, 2014). When decrying US standards as weak or less safe alike Friends of the Earth Europe (2013), they omitted to remark that mutual recognition or recognized equivalence of processes does not require either side to actually amend any laws or regulations. Worse still, their avalanche of reprehending position papers, social media posts, protests, and public statements were then even amplified through extensive media coverage. Their strategy proved to be effective since "polls kept showing declining support for TTIP, especially on food related issues, with a general public perception of the US as less regulated and more profit driven, resulting in lower safety standards" (Eliasson, 2015).

ISDS joined these controversial issues related to food (hormones, GMOs, sanitary processes, etc.) at the top of this anti-TTIP campaign. Again, NGOs utilized public media, wrote position papers, and issued press releases, alleging that an ISDS chapter would restrict policy making and create an unpredictable parallel justice by providing companies with legal redress against democratic decisions through suits in international tribunals. Their engagement paid off again as an official online survey on the denigrated arbitration bodies revealed that a large majority of participants disapprove of this practice. The rigid opposition to ISDS also worked its way into governments, with Germany and France demanding a renegotiation of the ISDS clause in CETA (Barbière, 2015). The Commission did not entirely abandon ISDS in response but put a reformed and more balanced mechanism of investor-state dispute settlement for TTIP on the table, whose blueprint was eventually incorporated into CETA (BMWI, 2017a). US representatives, unlike the Canadians, rejected the Commission's newly proposed scheme, though. In light of the excoriating public sentiment, the author wonders whether the refined ISDS mechanism would receive the necessary undivided assent of the European Parliament and EU member states at all, when it comes to ratifying a potential future transatlantic trade and investment partnership. The German government for instance takes the view that special provisions for investment protection are not needed in the first place because foreign investors enjoy sufficient legal protection in both jurisdictions through prudent national courts (BMWI, 2017b).

The cultural scene, too, has been eying the course of negotiations with suspicion. Although the cultural sector had been excluded from the Council's negotiation mandate right from the onset, some TTIP adversaries boldly aver that vital support measures, such as book price fixing or theater subsidies would come under fire (Cieschinger et al., 2016). They basically talked the public into believing that the treaty puts cultural diversity in jeopardy, with art and culture at large being downgraded to a mere commodity. To top it all off, detractors have been deftly tapping into the ubiquitous unease with big corporations and their influence on the world of work and society. They scared residents by prophesying that TTIP would unleash a wave of privatization, with all kinds of public services (drinking water, electricity, or garbage collection) falling into the hands of avaricious 
conglomerates at the expense of environmental or social aspects. If that was not enough, TTIP also became a proxy for unrelated issues, such as data privacy.

On balance, civil society groups have hitherto appeared far more successful than the business community in conveying their message and marketing their subjective narrative on TTIP. Over 500 million people live in the European Union and alone 3.2 million of them signed a petition against TTIP (Cieschinger et al., 2016). For sure, not an entire continent is revolting against the agreement. The number of signatures is nevertheless quite remarkable for a privately-organized campaign. All in all, it is perfectly understandable that the accumulation of negative headlines has thrown entire legions of European and American citizens into an utter panic over the TTIP. Legislators on both sides have notably responded to this mélange of scaremongering and legitimate concern with the pledge that lowering the level of health, safety, labor and environmental standards is off the cards (de Gucht, 2014).

But is it not too late to shut the stable door after the horse has bolted? The author is alluding to confirmation bias, a term typically used in the psychological literature. It connotes that we humans have a natural tendency to seek for information and interpret evidence in ways to validate existing beliefs, expectations, or a hypothesis in hand (Nickerson, 1998). This human characteristic leads us to accept both information and propaganda, with difficulty distinguishing between the two, whereby distortions of reality such as stories with omitted or misrepresented facts are readily believed and disseminated to other audiences (Bennett, Flickinger, Baker, Rhine, \& Bennett, 1996; Call \& Berry, 2011; Eliasson \& Huet, 2018). Our preference for consistency even implies that we subconsciously ignore information which is contradictory to one's own expectation and preconceived attitudes in order to avoid cognitive dissonance (Lamarre, Landreville, \& Beam, 2009).

To the author's mind, this whole episode also unveils a fundamental lack of trust in high ranking politicians and industry which cannot be easily fixed with a simple image campaign. Officials are hence well-advised to brace themselves as the highly skeptical nature of public debate around TTIP will most certainly impair its acceptance among the population. Politics, not macroeconomic predictions, will ultimately determine the fate of TTIP (Eliasson \& Huet, 2018). Politics, in turn, is biased by voter sentiment for what reason former US Ambassador to the European Union, Anthony Gardner (2015), admitted: "The deal will not collapse because of differences in standards or regulations, but rather from the perception that there is not enough upside for key constituencies".

Despite of having been reckoned as a potential promotor earlier on, President Trump embodies an external threat to the resumption of the TTIP negotiations at the same time. Concisely, it is him whose slogan "America First" entailed a paradigm shift in the White House. His rather unexpected victory at the ballot box has figuratively jolted both American society and the global order like a lightning bolt. Having campaigned on a protectionist platform, one of his first presidential acts was to irrevocably pull the US out of the TPP deal, a signature project of his antagonistic predecessor Barack Obama. TTIP talks came to an indefinite hold in the same breath, albeit, not terminated for good. Nonetheless,

Trump's protectionist convictions - his inaugural promise to buy American and hire American, as well as his readiness to deploy unilateral restrictive measures, even outside the World Trade Organization - promise to complicate many of the issues that bedeviled TTIP in the past. (Gardner, 2017)

With the massive protests still fresh in their memory, European leader will think twice before embarking on precarious TTIP negotiations with an American counterpart who is not less notorious for his habit of dividing people than for his undiplomatic and unpredictable actions. The global community has already witnessed his 
erratic conduct on plentiful occasions when he changed his mind from one day to another, or rather from one Tweet to another. One of the most memorable was the Group of Seven (G7) summit in La Malbaie, Canada in June 2018 when he caused a debacle of historic proportions. G7 leaders had, against all odds, actually managed to issue a joint communique after a tedious night-time session. But only about three hours after Justin Trudeau's closing press conference, a seemingly offended US President withdrew his endorsement for the final declaration with one single Tweet out of Air Force One, blaming the Canadian Prime Minister whom he defamed as "very dishonest and weak". It has just been one of the numerous cases which prove his destructive influence on multilateral fora. Since Donald Trump's swearing-in, the US has opted out of Iran nuclear deal, revoked its UNESCO (United Nations Educational, Scientific and Cultural Organization) membership, backed out of the Paris climate accord, fomented trade disputes, and even threatened to leave the World Trade Organization. Wherever you look, the US is irritating well-rehearsed practices of multilateral politics and tearing down the edifices of previous decades. Multilateralism per se appears to be a nuisance to the US president, being cleared away whenever it is in the short-term unilateral interests of his nationalistic agenda. These incessant affronts to the Europeans in world affairs must have wreaked havoc on the bond of trust, an indispensable component for sensitive trade negotiations.

But instead of reconciliation, even more upheaval is looming due to the US's unilateral exit from the Iran nuclear deal in May 2018 and the ensuing restoration of its sanctions on the Islamic Republic. Crucially, the White House announced to penalize also foreign companies with business links to the Gulf nation by, inter alia, seizing their assets in the United States. The outcry over these extraterritorial measures was naturally not long in coming amongst Europe's political elite. The bilateral relationship is now put to the acid test as the US government expressly refused to exempt EU firms from secondary sanctions, whereupon Brussels counteractively reinstalled its Blocking Statute (Council Regulation (EC) 2271/96) to mitigate their impact. By means of its updated scope, the "Blocking Statute allows EU operators to recover damages arising from US extraterritorial sanctions from the persons causing them and nullifies the effect in the EU of any foreign court rulings based on them" (EC, 2018b).

The hostilities could, in the author's view, even aggravate with a stronger dollar. The exchange rate for the Euro has decreased from $\$ 1.24$ in April 2018 to $\$ 1.15$ in September 2018. The appreciation of the dollar has actually been long overdue due to the Fed's (Federal Reserve Bank) progressive interest rate hikes from $0.75 \%$ in March 2017 to 2.00\% in June 2018. The base rates of the ECB (European Central Bank) and the Bank of Japan and elsewhere are, conversely, still stagnating at around zero. The central banks in Frankfurt and Tokyo will presumably not follow suit any time soon, either, as the economic recovery seems to grind to a halt in their territory. Induced by the US's robust economic development, the Fed's Board of Governors, in contrast, "signaled it would raise (borrowing) rates to 2.5 percent in 2018, 3.0 percent in 2019, and 3.5 percent in 2020" (Amadeo, 2018) in order to keep inflation at bay. The soaring federal funds rate will then prop up the US currency even further, and this does not bode well. A stronger dollar obviously renders imports cheaper and exports more expensive from the US's point of view. In other words, it will exacerbate the US trade deficit with the EU to the dismay of President Trump, adding fuel to the fire of an already tense transatlantic relationship.

Anyway, one thing is certain: At least one more hurdle towards a TTIP has popped up under President Trump. Consent on environmental standards will be more difficult to obtain with a country that has just withdrawn from the Paris climate agreement. CETA has most probably set a benchmark the EU is not prepared to fall behind. 
Is it possible that the EU, instead of President Trump, will eventually emerge as the spoilsport in this constellation? Yes it is! The Union has been bitterly plagued by various internal affairs of late. Firstly, Brexit alone inevitably implicates that the Commission is momentarily occupied head over heels with negotiating the terms of the exit and its concomitant future trade relationship with the UK. Whether it still has sufficient spare capacity left for forging ahead with the revival of TTIP remains to be seen.

Secondly, the alarming sovereign debt of several member nations is a source for sustained nervousness. While the EU in concert with its central bank and the IMF (International Monetary Fund) somehow succeeded in pooling enough resources to keep the midgets-Ireland, Cyprus, Portugal, and most prominently Greece-afloat when the euro zone contagion was raging, Brown (2014) reckoned that Italy "would be a different kettle of fish". Considering that the de facto default of tiny Greece had already plunged the European Monetary Union into an existential crisis, disorderly insolvency of a large member country like Italy would bring it, once and for all, to its knees. With its sovereign debt at 132\% of GDP, tantamount to a formidable total figure of $€ 2.32$ trillion (Trading Economics, 2018), the Italian Republic is plainly too big to fail and too big to bail. The financial woes of its ailing banks could swiftly evolve into the last straw that breaks the camel's back. The author is alluding to the so-called doom loop. Economist invented that term to describe a vicious circle where troubled credit institutes destabilize governments that come to their rescue while debt-laden governments in turn push bond holding banks over the precipice. This actually holds true for a host of Europe's banks "which — unlike their US peers that were recapitalized and subjected to rigorous stress tests soon after the global financial crisis erupted — remain saddled with non-performing loans (NPL) worth around $€ 1$ trillion and have been forced to grapple with negative interest rates, which have eroded their already weak profitability" (Spiro, 2018). Just imagine the fatal blow for the euro zone's cohesion, if those nightmare scenarios were to materialize.

Thirdly, the dissonance within the European Union surely has what it takes to derail a renewed attempt at TTIP. Europe's discernibly unprepared political elite has struggled to stem the massive inflow of refugees and migrants, letting alone to handle it in an orderly fashion. The overwhelming number of people landing on Europe's shores has not only incited political frictions over their distribution across member states but has also stirred up social unrest in the meantime. Measured by these dire straits, the vexation at the incremental democratic backsliding in Poland and Hungary or the flagrant weakening of anti-corruption laws in Romania seems subordinate. The massive influx took indeed an enormous toll on European solidarity and provided fertile soil for nationalistic populism as well as anti-Brussels sentiment within the different sections of society. A capricious political backlash against any of its prestige projects cannot be ruled out in this regard, egged on by the pervasive perception that free trade and globalization have mainly served the top one percent. After all, every member state as well as the European Parliament will have to ratify a future TTIP agreement before it can take effect. Figure 3 formidably visualizes that the first democratic hurdle towards this end represents the Council's approval of the brokered text. The body's consensus will be required since TTIP is to be classified as a so-called mixed agreement by also touching on areas of national competence. The US, in contrast, will merely submit it to simple up-or-down majority vote in Congress. Given the complementary signature of the American side, the treaty will be adopted, albeit, only provisionally. Because of its mixed competence, not only the European Parliament but also each national parliament has subsequently to decide in favor of the TTIP package for formal adoption. While Germany's constitution prescribes consent by the Bundestag and the Bundesrat, delicate referendums or regional parliaments will determine the fate of TTIP in other member states. Moreover, 
it will be too late to amend individual points since the latter is either accepted or rejected as a whole. In view of the aforementioned nationalistic movements and resentment towards Brussels, it is highly questionable whether a TTIP would survive this exhaustive ratification process. Just ask Canadian officials about their recent nerve-wracking encounter when the small Belgian region Wallonia brought the less lambasted CETA on the verge of collapse. 


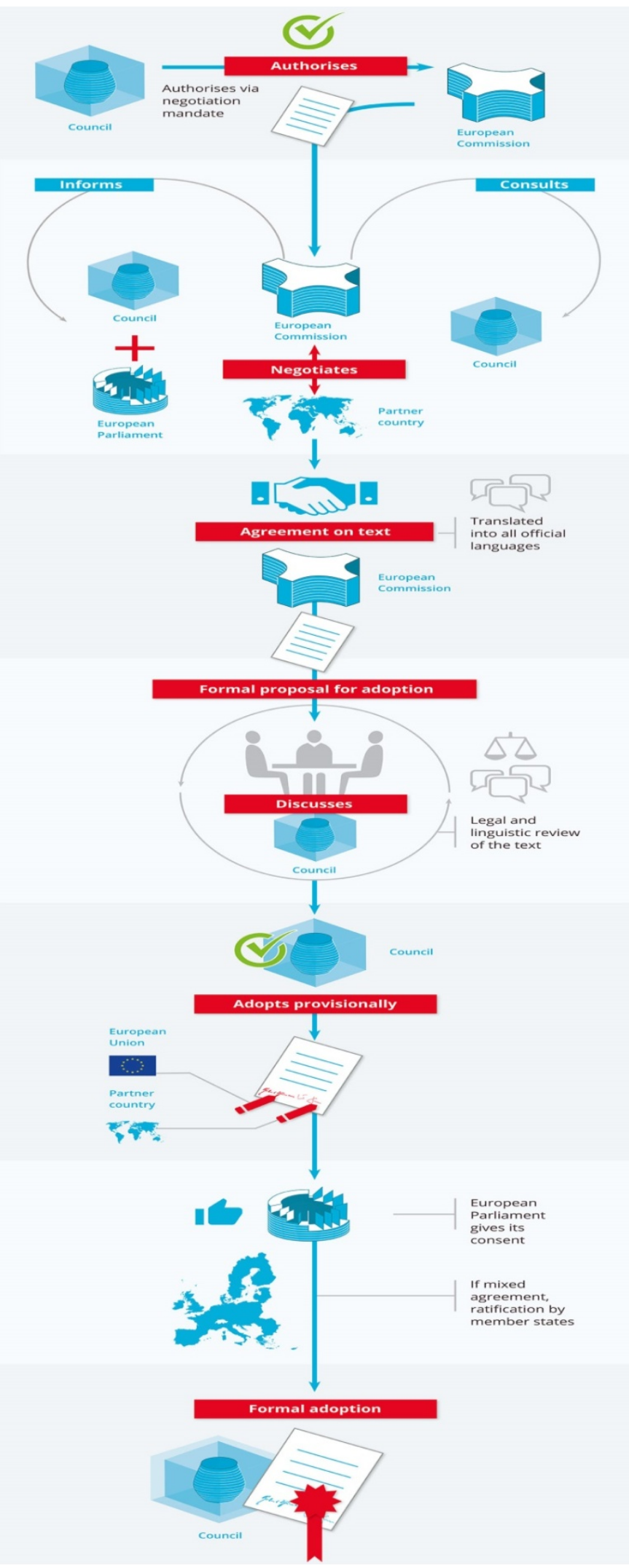

Figure 3. Operational sequence of EU trade negotiations; retrieved from the Council of the European Union (2016). 


\section{Summary of SWOT Analysis}

Figure 4 does justice to the SWOT methodology by condensing the analysis' key insights in the symptomatic scheme below.

\begin{tabular}{|c|c|}
\hline \multicolumn{2}{|c|}{ Internal Factors } \\
\hline & \\
\hline 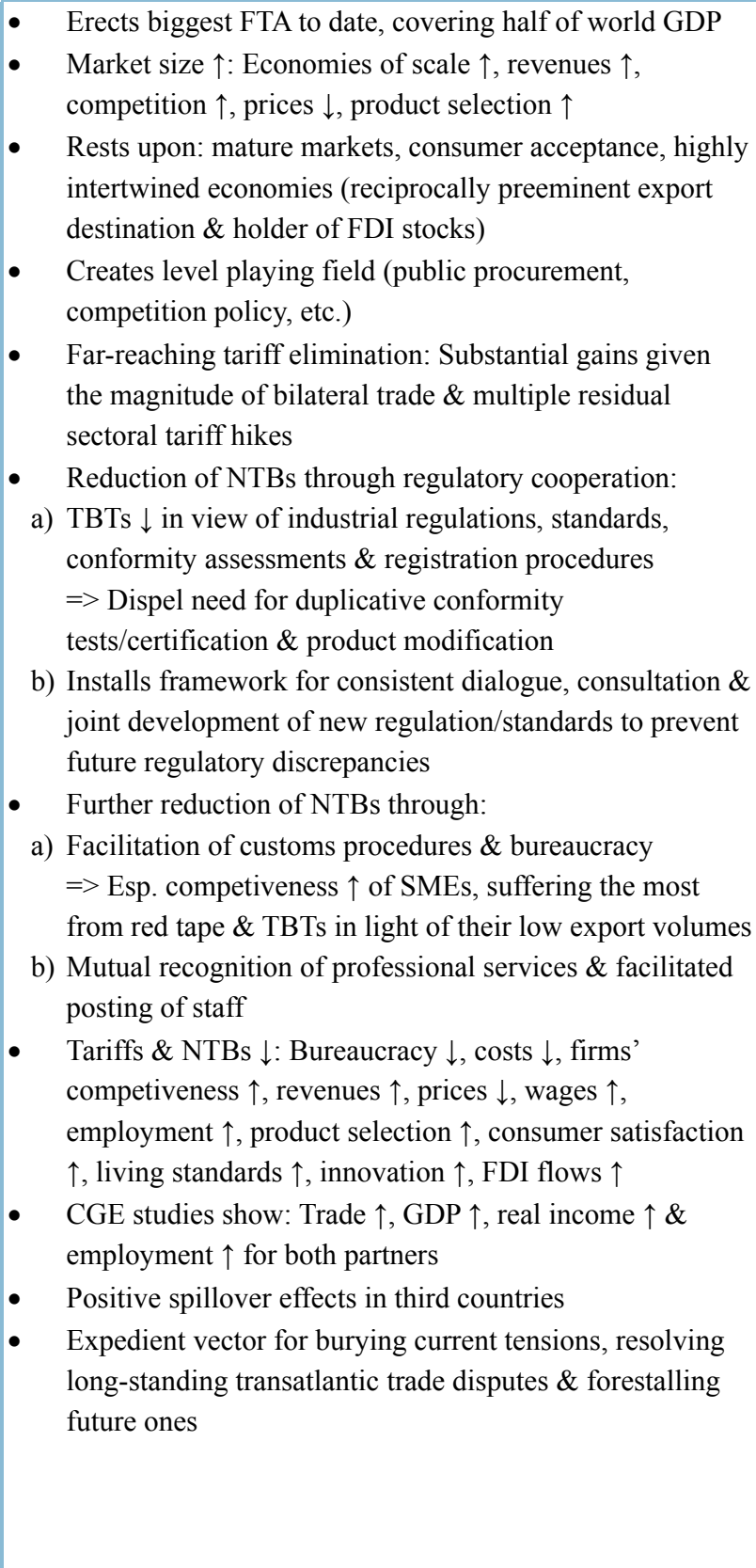 & 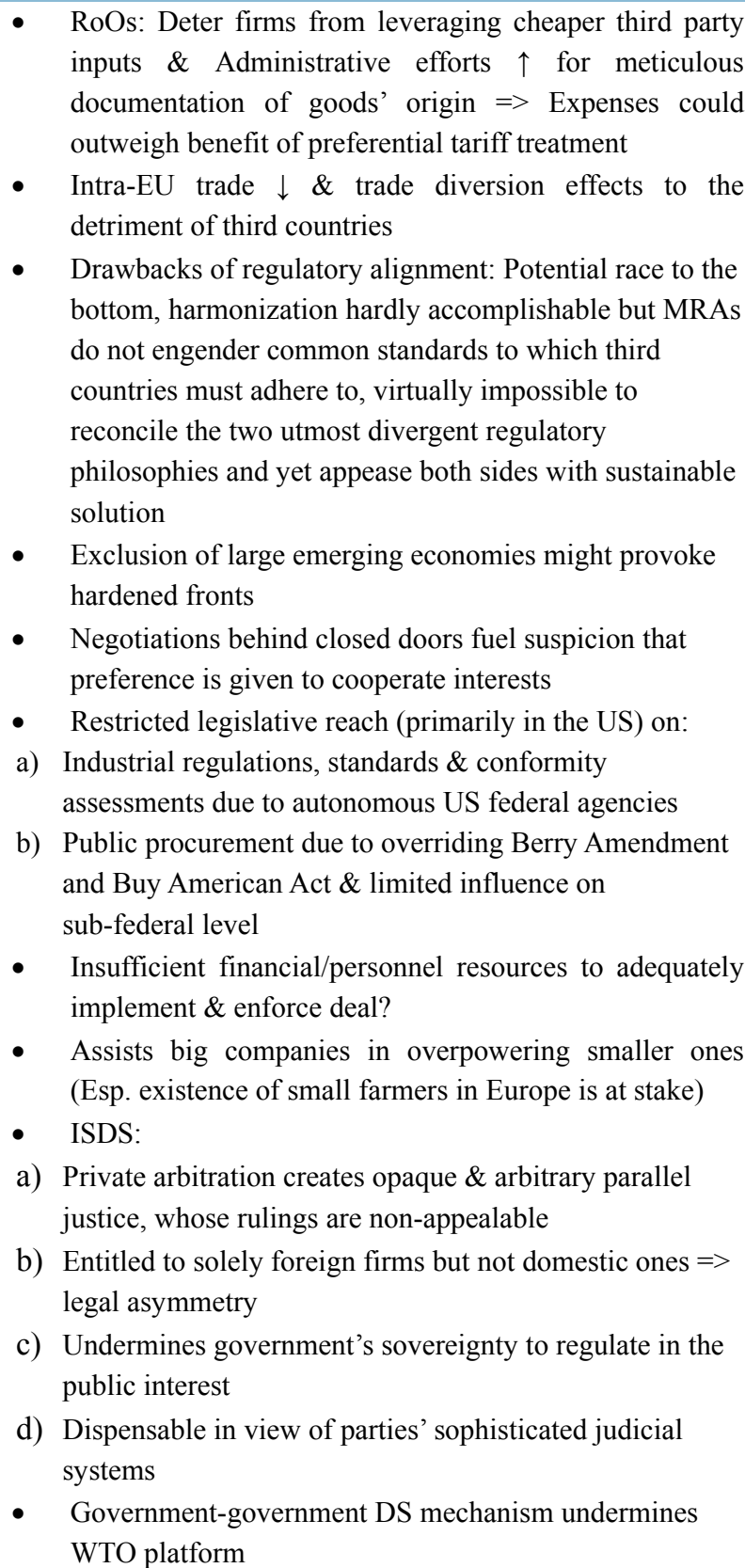 \\
\hline
\end{tabular}




\section{External Factors}

\section{Opportunities (+)}

- Dwindling economic clout/Rise of large NIEs:

$\Rightarrow$ Opportunity to curb this drift/counteract attack on their supremacy

$=>$ last chance to impose joint vision of 21 st century commerce (rules, regulations \& standards) on RoW \& preempt China from doing so instead

- No. of FTAs with other nations $\uparrow$ : Risk of being disadvantaged in each other's market in absence of their own bilateral one $=>$ CETA \& JEFTA incite Washington to resurrect bilateral talks in order not to be left out

- High public debts \& strained national budgets: Growth in exports, GDP \& wages is a compelling incentive to relaunch negotiations

- Influential business lobbies pushing for the agreement

- Untapped potential to capitalize on sustainability chapter in public discourse

- CETA \& JEFTA proves EU's affirmation of free trade

- TTIP as a catalyst for deepening Single Market \& disciplining reform-reluctant actors within EU

- Brexit incites EU to showcase its capability of achieving quicker \& better outcomes on a US-FTA

- President Trump: Temptation to portray himself as a great deal-maker \& sell deal as a vehicle to reduce US's trade deficit with EU

- Trump-Junker understanding in view of looming EU-US trade war could pave the way for relaunch of TTIP negotiations/converting quarrel into a launching pad for wider trade talks

- Key decision-makers across the Atlantic (Merkel, Ross, Altmeier, etc.) are overtly advocating for a relaunch

- Monsanto takeover by Bayer increases the odds of trailblazing European concessions on GMOs

- Chance to formulate globally relevant rules on $\mathrm{WTO}+$ and WTO-X policy areas $\Rightarrow>$ Restrain anti-competitive practices of China \& bridge current impasse in Doha Round

- $\quad$ Long sought-for sign of unity in economic \& political terms (resentment over Russian aggression, US-China trade war, etc.)
Threats (-)

- $\quad$ Effective campaigning of civil society groups against treaty (on ISDS, GMOs, hormones in meat, sanitary processes/chlorinated chicken, endangered cultural diversity, privatization of essential public services, weakening of labor \& environmental standards, etc.) => Consolidated public disapproval

- Poor prospects of winning back the populace due to:

a) Confirmation bias when facing a mélange of scaremongering and legitimate concern

b) Industry's marketing devoid of passion \& persuasion

c) Fundamental lack of trust in senior politicians

d) Politics, in turn, is biased by voter sentiment

- President Trump:

a) his protectionist convictions/“America First” policy will complicate many issues that bedeviled TTIP in the past, let alone consent on environmental standards following US's withdrawal of Paris climate agreement

b) Europeans hesitant to embark on precarious trade negotiations with undiplomatic \& unpredictable

American counterpart

c) Incessant affronts to EU in world affairs $=>$ wreaked havoc on bond of trust, an indispensable component for sensitive trade talks

d) Restoration of US sanctions against Iran (upon unilateral exit from Iran nuclear deal): Relationship put to the acid test after the White House refused to exempt EU firms from secondary sanctions

- Stronger dollar aggravates US's trade deficit with EU => adds further fuel to the fire

- European Union:

a) Plagued by various internal affairs (Brexit, Italy's alarming sovereign debt, ailing banks, democratic backsliding in Poland \& Hungary, weakening of anti-corruption laws in Romania, massive influx of refugees \& migrants, etc.) $=>$ Sufficient capacity left for promoting TTIP?

b) Nationalistic populism \& anti-Brussels sentiment on the rise $=>$ capricious political backlash against any of its prestige projects cannot be ruled out

c) exhaustive ratification process (incl. referendums in some countries) bears high risk of failure on the final straight 


\section{Concluding Remarks}

In view of the already relatively low MFN rates on average, today's most impeding barriers to transatlantic trade are not custom tariffs but so-called behind-the-border measures. Having delved into the originally intended structure and content of TTIP, the author concludes that it was destined to become a verily comprehensive trade and investment agreement in acknowledgment of this circumstance. In essence, the trade accord rests upon three distinctive pillars: (1) improved market access for industrial goods, agricultural products, services and government procurement through eliminating tariffs and reducing horizontal NTBs; (2) regulatory issues including not only horizontal chapters on regulatory coherence and TBTs but also specific industry-specific alignment; (3) broader trade related rules as well as joint development of golden standards on WTO+ and WTO-X type disciplines. It is fair to say, though, that this distinctively ambitious agenda exposed both camps' opposing positions on several fronts at the same time. In a nutshell, the TTIP is currently on hold not because it is a "bad thing" but because of conflicts of interest that are hard to reconcile. Considering that the negotiations had already hit several road blocks under the espousing Obama administration, the protectionist convictions and "America First" policy of the incumbent US President promise to complicate many of the contentious issues that bedeviled TTIP in the past. The scrutinizing comparative analysis also shows that the divergent approaches towards risk management, above all, translate into a formidable dilemma with regard to finding common ground on a broad range of topics. I suspect that one central prerequisite has not been met yet, namely mutual confidence in the counterpart's unfamiliar regulatory philosophy.

Having leveraged the SWOT analysis in the business environment on manifold occasions, the powerful technique also stood the test in the innovative context of identifying internal strengths and weaknesses of TTIP as well as external opportunities and threats to its conclusion further down the line. Figure 4 indicates that there is no clear-cut answer to the question: Would we all be better off with TTIP? Juxtaposing its intrinsic strengths and weaknesses shows a mixed picture, alike so often in real life where no absolute truth exists. Only one thing is certain: "A successful TTIP could be a game changer for both the transatlantic economy and for the rest of the world" (WTO, 2016). For all the pros and cons, one must not forget that the actual consequences of a transatlantic trade and investment agreement will strongly depend on the concrete final contractual arrangements - according to the saying: "The devil is in the detail". In any case, one does not get very far with an attitude based on commonplaces. For example, if trade agreements really impaired consumer protection, the EU would already suffer from weakened standards nowadays, which is obviously not the case. After all, European integration with its internal market is a free trade project in its own right that has been running for decades. A comprehensive transatlantic trade and investment partnership would in this sense act as a catalyst for promoting and deepening the highly esteemed Single Market. My research demonstrates that there are compelling economic incentives for revitalizing the bilateral talks on TTIP with respect to the likely transformations it would bring about in terms of market organization and functioning, production and distribution efficiency, national income, consumer satisfaction and, not least, regulation harmonization.

Examining the matter from a different angle by asking "What are the probable implications of the scenario where the negotiations on a transatlantic trade and investment agreement will not be reinstated in the near future?" provided further illuminating insights. This deliberate utilization of the antithesis revealed that neither of them can actually afford to perpetuate the current status quo. The mutual share in each other's imports has been steadily declining since the turn of the millennial. This phenomenon can mostly be ascribed to the 
coinciding rapid rise of predominantly Asian NIEs, whose enhanced competitiveness, output, and export volumes have changed the structure of world trade flows. Establishing the world's largest FTA offers both parties a golden opportunity to curb this drift and counteract the attack on their supremacy on the economic front. Without TTIP, the relative size of the transatlantic pole is bound to dwindle in the global economy. Let alone the long-term geostrategic damage caused by its absence, as the EU and the US would miss out on the last chance to impose their joint vision of 21 st century commerce (rules, regulations, standards, etc.) on the rest of the world and preempt China from doing so instead. American and European decision-makers should acknowledge that time is of the essence since Peking has already begun to contest the Western allies' ability to decide on the fate of global governance. A deal-despite of all its flaws and imperfections—is therefore also better than no deal from a consumer's perspective. Even though Washington and Brussels may argue about whose regulatory philosophy is the superior one, any trade-off will be far better than what China, India, South America, or Africa has to offer. The progressive evolution of the global economy towards a multipolar world order epitomizes in this connection an external opportunity for the resurrection of bilateral trade talks. Besides, the US and the EU are equally united in reprehending China's plethora of anti-competitive trade practices. History has shown that it often needs a common foe for alliances to solidify.

Apropos, a glance at the corresponding favorable and impeding external circumstances in Figure 4 suggests that the pendula could swing in either direction. Intriguingly, Donald Trump plays an ambiguous role in the game over the TTIP's destiny. President Trump reached a major milestone on 1 October 2018 when he finally managed to overhaul NAFTA in the US' favor in form of the superseding USMCA (US-Mexico-Canada Agreement). Considering his eagerness to portray himself as a great deal-maker in and his aspiration to reduce the US trade deficit with the EU, he will most probably henceforth concentrate on the transatlantic project, waiting next in line.

However, President Trump embodies an external threat to the relaunch of TTIP negotiations at the same time since his incessant affronts to the Europeans in world affairs have left burned bridges behind. It will necessitate more than the Trump-Junker rapprochement of July 2018 to rebuild those. Not least his sharp tongue and unpredictable behavior must have nurtured the perception of an untrustworthy American counterpart amongst European stakeholders. The author therefore believes that Brussels will be hesitant to re-embark on delicate TTIP negotiations until the next US presidential election in 2020, in the hope that a more amicable and more reliable Democratic nominee would enter the White House. The Commission will, in the author's opinion, be too distracted anyway by the coinciding Brexit from taking the initiative any time soon. The UK's exit represents a double-edged sword in this context, as the dueling race for a FTA with the US immediately will start once this all-consuming affair is settled and tied up capacities are recuperated.

But for also reaching the finishing line-synonymous for the successful ratification of TTIP-it is imperative to learn from the mistakes of the past.

Both camps must recognize that they are of equal size, wherefore neither of them will budge too easily. Hence, preparedness for compromise and quid pro quo is the order of the day. The general rule of thumb applies: You have to give up on some of your own rigid positions in order to hold your ground on others. For example, the EU ought to ponder on relaxing its tedious GMO approval procedures in order to reap Washington's concession on corresponding labelling requirements in return. A win-win situation would materialize where the White House satisfies the demands of the US industry and concerned European consumers, on the other hand, can consciously refrain from buying products they reject. The likelihood for this equally faces saving move increased indeed with the Monsanto takeover by Bayer, whose ensuing lobbying 
foreshadows a softening of Germany's critical stance on GMOs. Similarly, the American side is well-advised to settle for the proposed reformed mechanism à la CETA should it be adamant about ISDS until the bitter end. All in all, there is no point in pressing the EU on a deal, which does not stand any chance of ratification in national parliaments and, a fortiori, referendums. European heads of government must, conversely, advocate for the trade accord and sell it to their affiliated delegates and constituencies as the latter pays much more attention to domestic media than to Brussels' communiqués.

Transparency is not only crucial for dispute settlement but also for TTIP negotiations per se. The former conduct of negotiations behind closed doors fueled the suspicion that preference was given to corporate interests. The populace's perception of "backroom deals" insinuated that there was something to hide. This erstwhile lack of transparency is thus ought to be rectified (through e.g., public participation, disclosing negotiation objectives and progress reports, etc.) when both parties withdraw TTIP from its present deep freeze storage again. By the same token, we should demand discrediting NGOs to lay bare their opaque sources of funding and denigrating claims. Notably, those opposing civil society groups put officials on the back foot from the very beginning of public discourse, who perspicuously struggled to debunk the potpourri of myths and misconceptions in articulate, persuasive language. These past events forebode an uphill battle against confirmation bias and no lesser extent of scaremongering to be geared up for prospectively. Gardner (2017) appositely conceded: "We need to treat TTIP like a political campaign (next time), not just a trade negotiation. Simple falsehoods peddled on social media trump complex truths, especially when these truths are packaged as dry studies. While respecting the facts, we could have done a better job at making our case with passion”. But what kind of affirmative messages do actually connect with the populace? Leaving the services of focus groups and communications professionals aside, the author opines that aloof officials have to put themselves in the shoes of ordinary citizens if they want to formulate convincing narratives and draw the right lessons from past mistakes. The author hopes to have contributed to this end by the trains of thought and recommendations provided in this article.

\section{References}

Ahearn, R. (2009). Transatlantic regulatory cooperation: Background and analysis. Congressional Research Service Report $R L 34717$.

Akhtar, S., \& Jones, V. (2014). Transatlantic Trade and Investment Partnership (TTIP) negotiations. Congressional Research Service.

Amadeo, K. (2018). Current federal reserve interest rates and why they change [Online]. The Balance. Retrieved 4 September 2018, from https://www.thebalance.com/current-federal-reserve-interest-rates-3305694.

Barbière, C. (2015). Paris and Berlin call for review of EU-Canada trade deal. Euroactive, 27 January 2015.

Bartl, M., \& Fahey, E. (2014). The postnational marketplace: Negotiating the Transatlantic Trade and Investment Partnership. In E. Fahey and D. Curtin (Eds.), A transatlantic community of law: Legal perspectives on the relationship between the EU and US legal orders (pp. 210-234). Cambridge: Cambridge University Press.

Beck, S. (2014a). Assessing TTIP and its supporting studies. In C. Scherrer (Ed.), The Transatlantic Trade and Investment Partnership (TTIP): Implications for labor (pp. 10-99). Munich: Mering.

Beck, S. (2014b). TTIP: Possible negotiating outcomes and consequences. In C. Scherer (Ed.), The Transatlantic Trade and Investment Partnership: Implications for labor (pp. 10-40). Munich: Mering.

Bennett, S., Flickinger, R., Baker, J., Rhine, S., \& Bennett, L. (1996). Citizens' knowledge of foreign affairs. Harvard International Journal of Press/Politics, 1, 10-29.

Berden, K., Francois, J., Thelle, M., Wymenga, P., \& Tamminen, S. (2009). Non-tariff measures in EU-US trade and investment. An economic analysis. Rotterdam: ECORYS Nederland BV.

BEUC. (2014). Food and the Transatlantic Trade \& Investment Partnership (TTIP): BEUC position. The European Consumer 
Organisation (BEUC).

Blenkinsop, P. (2014). U.S. says science should settle farm debates in trade deal with EU. Reuters, 17 June 2014.

BMWI (2015). Transatlantische Handels-und Investitionspartnerschaft (TTIP) zwischen der EU und den USA Fakten und Informationen, häufig gestellte Fragen und Antworten. Berlin: Bundesministerum für Wirtschaft und Energie/Federal Ministry for Economic Affairs and Energy (Germany).

BMWI. (2017a). Comprehensive Economic and Trade Agreement (CETA) [Online]. Federal Ministry for Economic Affairs and Energy. Retrieved 6 July, 2017, from http://www.bmwi.de/Redaktion/EN/Artikel/Foreign-Trade/ceta.html.

BMWI. (2017b). Transatlantic Trade and Investment Partnership (TTIP) [Online]. Bundesministerum für Wirtschaft und Energie/Federal Ministry for Economic Affairs and Energy (Germany). Retrieved from 24 November, 2017 https://www.bmwi.de/Redaktion/DE/Dossier/ttip.html.

Bravo, R., \& Chatterley, J. (2018). Trump is willing to reopen TTIP amid EU-U.S. trade dispute, Ross says. Bloomberg, 29 March 2018.

Brown, D. (2014). Struggling Italian economy poses potential threat to whole of Europe. South China Morning Post, 28 April 2014.

Buchter, H., Pinzler, P., \& Uchatius, W. (2014). TTIP_Was handeln wir uns da ein? Die Zeit, 26 June 2014.

Burchard, H. (2017). Trump boosts free trade-outside US. Retrieved from http://www.politico.eu/article/trump-boosts-free-trade-outside-the-us/

Bureau, J., Disdier, A., \& Emlinger, C. (2014). Agriculture and rural development risks and opportunities for the EU agri-food sector in a possible EU-US trade agreement. Study for the directorate-General for internal policies policy. Department B: Structural and Cohesion Policies, Brussels: European Union.

Call, J., \& Berry, M. (2011). The dissemination of knowledge and its problems in American democracy. Public Knowledge Journal, 2, 1-9.

CEO. (2013). European Commission preparing for EU-US trade talks: 119 meetings with industry lobbyists [Online]. Corporate Europe Observatory. Retrieved from $\mathrm{http}$ //corporateeurope.org/trade/2013/09/europeancommission-preparing-eu-us-trade-talks-119-meetings-industry-lobbyists

Chase, P. (2011). Strengthening the transatlantic economy: The United States, European Union and international investment. Berlin: German Marshall Fund.

Cieschinger, A., Demling, A., \& Kuepper, M. (2016). Freihandel mit den USA: Alles über das TTIP-Abkommen—endlich verständlich. Spiegel, 16 September 2016.

Council, E. (Ed.). (2000). Council resolution on the precautionary principle, Annex III, annexes to the European Council conclusions, Bulletin EU 12-2000. Brussels.

Council of the European Union. (2013). Directives for the negotiation on the Transatlantic Trade and Investment Partnership between the European Union and the United States of America. Brussels: Council of the European Union.

Council of the European Union. (2016). Infographic_EU trade negotiations [Online]. Brussels: Council of the European Union. Retrieved 29 August, 2018, from http://www.consilium.europa.eu/en/infographics/eu-trade-negotiation/

Crolly, H. (2018). Die Zweifel an Junckers Trump-Deal wachsen. Welt. 29 July 2018.

De Gucht, K. (2014). TTIP-Zum Glück Kein Wahnsinn. Die Zeit. 13 Juni 2014.

De Ville, F. (2013). The promise of critical historical institutionalism for EU trade policy analysis. Journal of Contemporary European Research, 9, 618-632.

De Ville, F., \& Orbie, J. (2011). The European Union's trade policy response to the crisis: Paradigm lost or reinforced? European Integration Online Papers (EIOP), 15, Article 2.

Decreux, Y., Milner, C., \& Peridy, N. (2010). The economic impact of the free trade agreement between the European Union and Korea. Brussels: Centre d'Etudes Prospectives et d'Informations Internationales.

Diels, J., \& Thorun, C. (2015). Risks and opportunities for consumer welfare arising from the Transatlantic Trade and Investment Partnership (TTIP). Economic and Social Policy Unit of the Friedrich-Ebert-Stiftung.

Dieter, H. (2014). The structural weaknesses of TTIP: Transatlantic partnership threatens more than just consumer protection. SWP Comments, 32/2014. Berlin: Stiftung Wissenschaft und Politik-SWP-Deutsches Institut für Internationale Politik und Sicherheit.

Dietrich, V. (2014). Free trade: Strategy 2030-Wealth and life in the next generation. Berenberg.

Donnan, S. (2014). EU-US trade talks hit roadblock over financial services. Financial Times, 16 June 2014.

Draper, P., \& Freytag, A. (2014). Streitpunkt Investitionsschutz: Für und Wider des Investitionsschutzes im TTIP-Abkommen. 
Munich: Ifo Institut.

DW. (2017). Angela Merkel welcomes US offer to resume TTIP talks. Dw News, 27 June 2017.

EC. (2011). EU-US summit: Fact sheet on high-level working group on jobs and growth. Memo/11/843, Washington.

EC. (2013a). European Union and United States to launch negotiations for a Transatlantic Trade and Investment Partnership. Memo/13/95. Brussels: European Commission.

EC. (2013b). Impact assessment report on the future of EU-US trade relations. Commision Staff Working Document. Strasbourg: EC.

EC. (2014). EU-US Transatlantic Trade and Investment Partnership: Cooperation on financial services regulation. Brussels: European Commission.

EC. (2015a). Commission staff working document: Online public consultation on investment protection and investor-to-state dispute settlement (ISDS) in the Transatlantic Trade and Investment Partnership Agreement (TTIP). Brussels: European Commission.

EC. (2015b). Management Plan 2015. Brussels: European Commission, Directorate-General for Trade.

EC. (2017a). Countries and regions-Mexico [Online]. European Commission. Retrieved from http://ec.europa.eu/trade/policy/countries-and-regions/countries/mexico/

EC. (2017b). EU-Canada: Comprehensive Economic and Trade Agreement (CETA) [Online]. European Commission. Retrieved February 19, 2017, from http://trade.ec.europa.eu/doclib/press/index.cfm?id=1723.

EC. (2017c). Trade-United States [Online]. European Commission. Retrieved September 17, 2017, from http://ec.europa.eu/trade/policy/countries-and-regions/countries/united-states/

EC. (2018a). Conformity assessment [Online]. European Commission. Retrieved July 5, 2018, from https://ec.europa.eu/growth/single-market/goods/building-blocks/conformity-assessment_en.

EC. (2018b). Updated blocking statute in support of Iran nuclear deal enters into force. Brussels: European Commission.

EFSA. (2005). Opinion of the scientific panel on food additives, flavourings, processing aids and material in contact with food (AFC) on a request from the commission related to treatment of poultry carcasses with chlorine dioxide, acidified sodium chlorite, trisodium phosphate and peroxyacids. EFSA Journal, 297, 1-27.

Eliasson, L. (2015). The Transatlantic Trade and Investment Partnership: Interest groups and public opinion. European Union Studies Association's 14th Biennial Meeting. Boston: European Union Studies Association.

Eliasson, L., \& Huet, P. (2018). TTIP negotiations: Interest groups, anti-TTIP civil society campaigns and public opinion. Journal of Transatlantic Studies, 16, 101-116.

Esslinger, D. (2014). TTIP-Faktencheck: Arbeitnehmerrechte-Machtgefälle in Fabrik und Büro. Sueddeutsche Zeitung. 15 August 2014.

Eurostat. (2018). Foreign direct investment-stocks [Online]. Eurostat. Retrieved July 10, 2018, from http://ec.europa.eu/eurostat/statistics-explained/index.php?title=Foreign_direct_investment_-_stocks.

FDA. (1992). Statement of policy_Foods derived from new plant varieties. 57, Fda Federal Register. Washington: Food and Drug Administration (FDA).

Federal Ministry of Food and Agriculture. (2011). Agrarstrukturen in Deutschland. Einheit in Vielfalt. Regionale Ergebnisse der Landwirtschaftszählung 2010. Stuttgart: Statistische Ämter des Bundes und der Länder.

Felbermayr, G. (Ed.). (2013). Transatlantic Trade and Investment Partnership (TTIP), who benefits from a free trade deal? Bertelsmann Foundation.

Felbermayr, G., \& Larch, M. (2013). The Transatlantic Trade and Investment Partnership (TTIP): Potentials, problems, perspectives. Cesifo Forum, 14(2), 49-60.

Fernandez-Cornejo, J., Wechsler, S., Livingston, M., \& Mitchell, L. (2014). Genetically engineered crops in the United States. Economic Research Report 162. Washington: U.S. Department of Agriculture (USDA) and Economic Research Service (ERS).

Fontagné, L., Gourdon, J., \& Jean, S. (2013). Transatlantic trade: Whither partnership, which economic consequences? In L. Fontagné (Ed.), CEPII-policy brief. Centre d'Etudes Prospectives et d'Informations Internationales (CEPII).

Francois, J. (2013). Reducing transatlantic barriers to trade and investment, an economic assessment. Final Project Report Under Implementing Framework Contract Trade 10/A2/A16. London: CEPR.

Friends of the Earth Europe. (2013). Trading away our future? A threat to Europe's democracy and environmental, health, and social safeguards. Position Paper of Friends of the Earth Europe on the Transatlantic Trade and Investment Partnership (TTIP), October 2013. Brussels: Friends of the Earth Europe. 
Fritz, T. (2014). TTIP vor Ort. Folgen der transatlantischen Handels-und Investitionspartnerschaft für Bundesländer und Kommunen. Campact.

Gardner, A. (2015). Speech at the EU-US industry trade day. Brussels, 5 February 2015.

Gardner, A. (2017). Ho to revive TTIP. Politico, 12 May 2017.

Ghibutiu, A. (2015). The revival of trade regionalism: Determinants, patterns, and implications. Knowledge Horizons-Economics, $7,9-14$.

Gibbons, M. (2012). Letter from Michelle Gibbons, chair, EU-U.S. task force, American chamber of commerce to the European Union, regarding call for input on regulatory issues for possible EU-U.S. trade agreement. 31 October, 2012.

Hamilton, D. S., \& Pelkmans, J. (2015). Rule-makers or rule-takers? Exploring the Transatlantic Trade and Investment Partnership. London: Rowman \& Littlefield International, Ltd.

Hart, A. (2010). How do rising powers rise? Survival, 52, 63-88.

Hay, C. (2007). Keynote article: What doesn't kill you can only make you stronger: The Doha development round, the services directive and the EU's conception of competitiveness. Journal of Common Market Studies, 45, 25-43.

HLWG. (2013). Final report: High level working group on jobs and growth. High Level Working Group on Jobs and Growth.

Holmes, P., \& Dawar, K. (2016a). The TTIP trade deal is lost at sea. The Conversation, 7 June 2016.

Initiative Neue Soziale Marktwirtschaft. (2016). 12 Fakten zu TTIP/12 facts about TTIP [Online]. Retrieved August 14, 2018, from http://www.insm.de/insm/Themen/Soziale-Marktwirtschaft/12-fakten-zu-ttip.html.

ITC. (2018). WTO: Non-tariff measures; Part 3: Difference between standards and technical regulations [Online]. Retrieved July 3, 2018, from http://www.intracen.org/Part-3-Difference-between-standards-and-technical-regulations/

Janker, K. (2015). Folgen von TTIP für die Entwicklungsländer: Verlieren werden die Ärmsten. Süddeutsche Zeitung. 15 August 2014.

Jones, V., \& Rosenblum, M. (2013). U.S. customs and border protection: Trade facilitation, enforcement, and security. CRS Report R43014. Congressional Research Service.

Josling, T., \& Crombez, C. (2013). The political economy of transatlantic free trade. Working Paper 7/17/13.

Josling, T., \& Tangermann, S. (2014). Agriculture, food and the TTIP: Possibilities and pitfalls. Special Report No. 99. Brussels: Center For European Policy Studies.

Kahn, U., Pallot, R., Taylor, D., \& Kanavos, P. (2015). The Transatlantic Trade and Investment Partnership: International trade, law, health systems and public health. The London School of Economics and Political Science.

Kolev, G. (2016). Ein differenzierter Blick auf die kontroverse TTIP-Debatte. TTIP_Probleme und chancen. Wirtschaftsdienst.

Lamarre, H., Landreville, K., \& Beam, M. (2009). The irony of satire: Political ideology and the motivation to see what you want to see in the Colbert report. The International Journal of Press/Politics, 14, 212-231.

Liu, J., \& Self, L. (2012). Trade secret theft: Managing the growing threat in supply chains. Washington: Center for Responsible Enterprise and Trade.

Macdonald, J. (2013). Farm size and the organization of U.S. crop farming. Economic Research Report No. (ERR-152). United States Department of Agriculture.

Malmstroem, C., \& Froman, M. (2017). U.S.-EU joint report on TTIP progress to date. Executive Office of the President of the United States European Commission.

Mellon, M. (2013). Weaker antibiotic regulation: Another problem with FDA's voluntary cooperation program [Online]. Union of Concerned Scientist. $\quad$ Retrieved June $22, \quad$ from https://blog.ucsusa.org/margaret-mellon/weaker-antibiotic-regulation-another-problem-with-fdas-voluntary-cooperation-prog ram?.ga=2.172719267.1411879092.1529794370-679537315.1529794370.

Meltzer, J. (2015). The internet, cross-border data flows and international trade. Asia \& the Pacific Policy Studies, 2, 90-102.

Mildner, S. (2015). Wir wollen TTIP; Klare Regeln—echte Chancen: Ein starkes TTIP für Deutschland. Berlin: Bundesverband der Deutschen Industrie e.V. (BDI).

Moïsé, E., Orliac, T., \& Minor, P. (2011). Trade facilitation indicators: The impact on trade costs. Oecd Trade Policy Working Papers, No. 118. The Organisation for Economic Co-operation and Development (OECD).

Müftüler, B., \& Cihangir, D. (2012). The transatlantic relationship and the future global governance. Transworld.

National Research Council. (1995). Standards, conformity assessment, and trade into the 21st century. Danvers, Ma, National Academies Press.

Nickerson, R. (1998). Confirmation bias: A ubiquitous phenomenon in many guises. Review of General Psychology, $2,175-220$.

Pollack, M. (2003). The political economy of the transatlantic partnership. Robert Schuman Centre for Advanced Studies, 
European University Institute.

Posner, E. (2009). Making rules for global finance: Transatlantic regulatory cooperation at the turn of the millennium. International Organization, 83, 665-699.

Radauer, A. (2009). Transatlantic IPR collaboration: An explorative analysis of counterfeiting, privacy and IP enforcement with special emphasis on policy approaches in the EU and the U.S. Vienna: KMU Forschung Austria/Austrian Institute for SME Research.

Rudloff, B. (2014). Lebensmittelstandards in Handelsabkommen: Unterschiedliche Regelungstraditionen von EU und USA und Tipps für TTIP. Berlin: Stiftung Wissenschaft und Politik (SWP): Deutsches Institut für Internationale Politik und Sicherhei.

Schimpf, M. (2013). GM crops irrelevant in Europe. Brussels: Friends of the Earth Europe.

Schmelzer-Roldán, S. (2014). The impact of electricity sector privatization on employees in Argentina and Brazil. A comparative institutional analysis. Munich: Rainer Hampp Verlag.

Schott, J. (2013). Crafting a transatlantic tradeand investment partnership: What can be done. Policy Brief, PB13.

Seitzinger, M. V. (2013). Foreign investment in the United States: Major federal statutory restrictions. Washington: Congressional Research Service (CRS).

Shao, Q., Punt, M., \& Wesseler, J. (2015). Trade liberalization on the EU-US GMO agreement: A political economy approach. GMCC Amsterdam 2015. Amsterdam: Seventh International Conference on Coexistence between Genetically Modified (GM) and non-GM based Agricultural Supply Chains (GMCC-15).

Siles-Brügge, G. (2011). Resisting protectionism after the crisis: Strategic economic discourse and the EU-Korea free trade agreement. New Political Economy, 16, 627-653.

Smith, M. (2010). A liberal grand strategy in a realist world? Power, purpose and the EU's changing global role. Journal of European Public Policy, 18, 144-163.

Spiegel. (2017). Handelsstreit-US-Regierung geht ein bisschen auf Deutschland zu. Retrieved from http://www.spiegel.de/wirtschaft/unternehmen/usa-gehen-im-handelsstreit-ein-bisschen-auf-deutschland-zu-a-1169989.html

Spiro, N. (2018). Will Italy and its ailing banks trigger the next global financial crisis? South China Morning Post, 8 June 2018.

Steffenson, R. (2005). Managing EU-US relations. Actors, institutions and the new transatlantic agenda. Manchester and New York: Manchester University Press.

Stoppttip! (2018). Alliance [Online]. Retrieved August $30, \quad 2018$, from https://stop-ttip.org/de/unterstutzerorganisationen/?noredirect=de_DE.

Stratman, K. (2018). Was Peter Altmaiers Kampf für TTIP light so schwer macht. Handelblatt. 6 May 2018.

Subramanian, A., \& Kessler, M. (2013). The hyperglobalization of trade and its future. Working Paper Series. Washington: Peterson Institute for International Economics.

Sueddeutsche. (2017). Merkel für neuen Anlauf bei TTIP. Sueddeutsche Zeitung, 27 June 2017.

TABC. (2017). Transatlantic Economic Council [Online]. Transatlantic Busniess Council. Retrieved November 24, 2017, from https://www.transatlanticbusiness.org/policy/transatlantic-fora/transatlantic-economic-council.

The Economist. (2014). Investor-state dispute settlement: The arbitration game. The Economist, 11 October 2014.

The Fed. (2017). Reserve requirements [Online]. The Federal Reserve. Retrieved September 21, 2018, from https://www.federalreserve.gov/monetarypolicy/reservereq.htm.

The Guardian. (2018). Trump-Juncker "talks about talks" met with scepticism. 26 July 2018.

Trading Economics. (2018). Italy general government debt [Online]. Retrieved September 7, 2018, from https://tradingeconomics.com/italy/government-debt.

USTR. (2013a). 2013 National trade estimate report on foreign trade barriers. Washington: United States Trade Representative.

USTR. (2015). National trade estimate report on foreign trade barriers. Washington: United Sates Trade Represenative (USTR).

Van De Zande, R. (2000). The role of standards in European conformity assessment. [Online] Standardization News. Retrieved from https://www.astm.org/SNEWS/DECEMBER_2000/dec_vandezande.html

Von Petersdorff. (2018). Überraschende Einigung im Handelsstreit. Frankfurter Allgemeine, 25.07.2018.

Winters, L. (1999). Regionalism versus multilateralism. World Bank Policy Working Paper 1687.

WTO. (2012). Trade faciliation [Online]. Retrieved from http://gtad.wto.org/trta_subcategory.aspx?cat=33121

WTO. (2016). TTIP and the EU Member States: An assessment of the economic impact of an ambitious Transatlantic Trade and Investment Partnership at EU Member State level. Bern: Who.

WTO. (2017a). International trade and market access data. Geneva: World Trade Organization. 
WTO. (2017b). Trade profiles 2017. Geneva: World Trade Organization.

WTO. (2018a). European Union-Tariff profile [Online]. Retrieved June 13, 2118, from http://stat.wto.org/TariffProfiles/E28_e.htm.

WTO. (2018b). Trade and tariff maps [Online]. Geneva: WTO. Retrieved May 29, 2018, from https://www.wto.org/english/res_e/statis_e/statis_maps_e.htm.

WTO. (2018c). United States of America-Tariff profile [Online]. Retrieved June 14, 2018, from http://stat.wto.org/TariffProfiles/US_e.htm?_sm_au_=iVVQZn7J0Qqr6vWR.

Yong, W. (2014). The political economy of the rise of mega-regionals. In World Economic Forum (pp. 20-21). 